\title{
Rapid expansion of international new ventures across institutional distance
}

Ziliang Deng ${ }^{1}$ (1), Ruey-Jer "Bryan" Jean"2 and Rudolf R Sinkovics ${ }^{3,4,5}$

\footnotetext{
${ }^{1}$ Renmin Business School, Renmin University of China, Beijing 100872, China; ${ }^{2}$ Department of International Business, National Chengchi University, Taipei, Taiwan, China; ${ }^{3}$ Alliance Manchester Business School, The University of Manchester, Manchester, UK; ${ }^{4}$ Lappeenranta University of Technology, Lappeenranta, Finland; ${ }^{5}$ Fox School of Business, Temple University, Philadelphia, USA

Correspondence:

Z Deng, Renmin Business School, Renmin University of China, Beijing 100872, China. Tel: (86)-10-82500498;

e-mail: ziliang.deng@ruc.edu.cn
}

\begin{abstract}
Rapid export expansion into institutionally distant locations has become more possible in the era of digital economy. Will such rapid expansion bring desirable outcome to firms? In a context of international new ventures (INVs) from emerging markets, we reconceptualize export expansion speed as the pace of exporting across institutional distance over a certain period of time. We then examine the relationship between rapid export expansion across institutional distance and overall firm performance. We incorporate directionality into export expansion and hypothesize the relationship to be positive when INVs export upwardly to more open countries, yet the relationship to be negative when INVs export downwardly to less open countries. We also hypothesize that the degree of market liberalization in subnational regions of origin of the INVs moderates the above speed-performance relationships. Instrumental variable models based on data of Chinese indigenous INVs during 2000-2009 support these hypotheses. This study both zooms in and zooms out the analytical lens along the location-related institutional axis, examines the joint effect of institutions involved in supranational directions and subnational origins on firm performance, and advances institutional theory.
\end{abstract}

Journal of International Business Studies (2018) 49, 10 10-1032. https://doi.org/ | 0.1057/s4 1267-017-0108-6

Keywords: international new ventures (INVs); institutional distance; learning advantages of newness; diseconomies of time compression; emerging markets; instrumental variable models

The online version of this article is available Open Access

\section{INTRODUCTION}

Rapidly expanding exports to institutionally distant locations has become more possible for international new ventures (INVs) given the unprecedented convenience in gathering information from overseas markets with modern information and communication technologies (Oviatt \& McDougall, 1994; Yamin \& Sinkovics, 2006). Despite the increasing possibility of exploring new markets, two intriguing and important location-centric institutional issues emerge. The first issue is the destination location and its associated institutional environment of the rapid export expansion. The destination country is crucial for the performance of international business (Makino, Isobe, \& Chan, 2004). On one hand, exporters from emerging markets may prefer to rapidly expand into more

open countries because these markets host more transparent and
Received: 1 November 2015

Revised: 31 July 2017

Accepted: 15 August 2017

Online publication date: 20 October 2017 
mature institutions. However, the countries offer equal market access to all exporters worldwide. Thus, the rapidly mounting pressure caused by post-entry competition in these destination markets is challenging. On the other hand, exporters may choose to venture into destination countries that are less open. Despite benefits such as low local competition, rapid entry into such markets involves daunting entry costs and post-entry uncertainties. Both directions of rapid market expansion pose challenges to nascent firms that usually lack strong organizational resources, e.g., diseconomies of time compression (Vermeulen \& Barkema, 2002), conflicts between organizational learning and unlearning associated with exposures to different institutions (Autio, Sapienza, \& Almeida, 2000; Zhou \& Guillén, 2015). Which direction of rapid export expansion is better, upward one into more open countries or downward one into less open countries?

The second issue concerns the location and associated institutions of subnational origin of the INVs conducting rapid export expansion. Most countries in the world exhibit a certain degree of regional variations in institutions (Chan, Makino, \& Isobe, 2010). For example, in Mexico, it took only two days to register a property transfer in Colima, but it took 74 days in Mexico City in 2013 (World Bank, 2016, p. 23). In particular, a terraced pattern in liberalization is commonly observed across different subnational regions and industries, particularly within a country transitioning from a centrally planned status to a deregulated one (Zhou, Tse, \& $\mathrm{Li}$, 2006). Thus, another question arises: will INVs originating from more liberalized regions acquire better financial returns in rapid expansion across institutional distance?

Motivated by the two location-centric questions, we draw on the notions of learning advantages of newness (Autio et al., 2000) and diseconomies of time compression (Vermeulen \& Barkema, 2002) to build a theoretical model on why and how rapid export expansion across national institutions matters. We reconceptualize internationalization speed by examining how fast an INV expands across national difference in trade openness. Trade openness refers to an economy's overall level of openness for products and services imported from foreign countries (Edwards, 1993). Trade openness affects exports most directly among various institutional dimensions. We focus on INVs as they are featured with an innovative, proactive, and risktaking organizational culture (Oviatt \& McDougall, 2005), and are rather possible to explore institutionally distant markets.

We posit that the rapid upward export expansion of INVs from less open home markets to more open destination markets positively affects firm performance. The underlying factor is the strong learning advantages of newness caused by rapid efficiency improvement, preview of pro-market institutions, and lower cost structure (Barnett \& McKendrick, 2004; Dau, 2013). By contrast, we argue that rapid downward export expansion of INVs from emerging markets to a less open destination market generates net negative effects on firm performance as a result of significant diseconomies of time compression associated with rapid cost surge and conflicting organizational routines (Hashai, 2011; Vermeulen \& Barkema, 2002). Finally, we encapsulate subnational institutional heterogeneity into the theoretical framework. We argue that location in liberalized subnational home country regions strengthens the positive relationship between rapid upward expansion and firm performance while weakening the negative relationship between rapid downward expansion and firm performance. To test these hypotheses, we employed panel data of 8681 Chinese manufacturing INVs from 31 provinces from 2000 to 2009. After controlling for potential endogeneity in export expansion speed, the empirical findings consistently support the hypotheses.

This study makes several contributions to the literature. First, the study incorporates an institutional perspective into the literature on internationalization process and INVs, and enriches the construct of internationalization speed that has examined timing, country scope, and foreign commitment dimensions (Oviatt \& McDougall, 2005). Second, it challenges the widely accepted norm for analyzing institutional distance and derived constructs. The study incorporates direction of distance (Dau, 2013; Tsang \& Yip, 2007; Zaheer, Schomaker, \& Nachum, 2012) and conceptualizes upward and downward export expansion speeds. Third, the study assesses if and how rapid upward and downward export expansions generate opposite effects on firm performance and complements the literature that has overly underscored the negative effects of institutional distance and associated concepts (Stahl, Tung, Kostova, \& Zellmer-Bruhn, 
2016). Fourth, this study advances institutional theory from a locational perspective by examining the joint effect of different aspects of institutions (Holmes, Miller, Hitt, \& Salmador, 2013), namely heterogeneity in supranational institutional distance and heterogeneity in subnational institutional quality.

\section{LITERATURE}

\section{Internationalization Speed, INVs, and Performance}

The literature examines internationalization speed mainly in three dimensions (Kuivalainen, Sundqvist, \& Servais, 2007), namely earliness of initial foreign entry or post-entry expansion pace ( $\mathrm{Li}$, Qian, \& Qian, 2015; Reuber, Dimitratos, \& Kuivalainen, 2017; Sapienza, Autio, George, \& Zahra, 2006), scope of country (Hashai, 2011; Vermeulen $\&$ Barkema, 2002), and intensity of foreign commitment (Li, Qian, \& Qian, 2012; Oviatt \& McDougall, 2005). The first dimension (timing) is essential (Rahaman, 2016), as it has become a common practice to define INVs if they start international business within 6 years of inception (Coviello, 2015; Deng, Jean, \& Sinkovics, 2017). Nonetheless, institutional dimension is overlooked in the literature. Considering the heterogeneity in institutional environment, examining the effect of rapid supranational institutional exposure on organizational routines and performance bears great strategic importance.

Rapid internationalization is challenging to organizations because of diseconomies of time compression, which arise when organizations are unprepared to accommodate rapid expansion and new experiences (Vermeulen \& Barkema, 2002). Rapid internationalization exposes firms to different customers, competitors, suppliers, institutions, and knowledge in a rather short period. Potential conflicts of business practices cause managers to devote suboptimal attention to each overseas project.

In contrast, for INVs, unfavorable shocks caused by rapid internationalization could be counterbalanced by the firms' intrinsic learning advantages of newness (Autio et al., 2000; Sapienza et al., 2006). Unlike older firms, INVs bear minimal burden of old organizational routines established for their home market environment. Therefore, INVs are more capable of unlearning old routines and constructing new routines for identifying, evaluating, and exploring global emerging opportunities (McDougall \& Oviatt, 2000).

\section{Heterogeneity in Subnational Institutions ${ }^{1}$}

Institutions within a country exhibit both homogeneity and heterogeneity. With national borders as stabilizers (Daniels, Radebaugh, \& Sullivan, 2014), institutions are homogenous within a country in some dimensions, e.g., import tariffs, and non-tariff import barriers. Subnational governments in most countries, particularly the member states of the World Trade Organization (WTO), possess no authority to design their own trade policies. For example, in Brazil, all nine major measures directly affecting its imports are formulated by country-level government agencies (WTO, 2013).

Nonetheless, the other dimensions of subnational institutions may diversify (Gao et al., 2017). Many formal regulative institutions formulated by central or federal governments are eventually interpreted and implemented by subnational government agencies. The subnational differences in the endowments of resources, culture, and historical legacy also lead to variations in institutions (Chan et al., 2010; Kirkman et al., 2017; Ma et al., 2013a). In particular, subnational heterogeneity in government intervention and legislative environment widely exists in emerging markets (Chan et al., 2010; Ma, Tong, \& Fitza, 2013b; World Bank, 2016). Managers need to calculate the benefits and costs associated with subnational locations (Ma et al., 2013a).

\section{HYPOTHESES}

\section{Supranational Expansion Speed, Direction, and Performance of INVs in a Trade Openness Context}

We confine hypothesis development to the relationship between export expansion speed and performance of INV manufacturers from emerging markets in a trade openness context, since exporting is the most typical form of internationalization adopted by INVs or born global firms (Cavusgil \& Knight, 2015). Exporters are surrounded by various institutional environments in destination markets, e.g., legal, cultural, and regulative ones, but not all institutional dimensions bear the same importance for international business (Cuervo-Cazurra \& Genc, 2008 , p. 963). One of the most pertinent dimensions for exporters is trade openness or 
liberalization (Baggs \& Brander, 2006; Khandelwal, Schott, \& Wei, 2013). Trade openness, as a form of formal institution, refers to the efforts of a government to lower both import tariffs and non-tariff barriers against foreign products (Edwards, 1993). By deconstructing institutions and focusing on this single institutional dimension (Zaheer et al., 2012, p. 22), we streamline hypothesis development by articulating the detailed mechanisms of how the speed of export expansion across institutional distance in trade openness affects firm performance. We discuss the independent effects of expansion speed and direction on the firm performance of INVs, and then we examine their joint effects.

\section{Speed and Performance}

In the trade openness context, we extend the construct of internationalization speed in the institutional dimension. We conceptualize export expansion speed across institutional distance as how fast an exporter expands to a market with a different degree of trade openness within a certain period. This new construct of speed may explicitly underscore shocks to organizational routines and reconfiguration (Autio et al., 2000). A firm rapidly exporting to countries with different degrees of trade openness will encounter different country institutional profiles (Kostova, 1999). Therefore, it needs to unlearn some old organizational routines and simultaneously construct new routines for the new institutional environment.

The difference between old and new routines exists saliently in two forms. The first difference arises between (old) home-oriented routines and (new) export-oriented ones. INVs should ensure that their organizational routines in their product design, manufacturing, marketing, and sales teams are oriented toward foreign market institutions. For example, when a toy manufacturer rapidly exports its toys to the European Union, the products must satisfy a series of EN71 standards on toy safety, which act as a form of technical barrier to trade (WTO, 2012). This series of standards requires the firm to rapidly implement internationalized, highquality management routines during raw material procurement and assembly. The health, safety, and compliance issues of INVs are monitored by the home country government, however. Therefore, organizational routines in human resources and government relations management are focused on local government requirements. As institutions are embedded in specific contexts, local government requirements differ from foreign ones (Kostova, 1999). Such a difference potentially causes conflicts between organizational routines.

The second difference exists between routines tailored for (old) existing destination markets and those for new markets. For example, a food-processing firm faces the strictest safety and sanitary standards in the US market, but it faces loosely regulated markets in other countries. When the firm simultaneously engages in rapid export expansion into both types of markets, it encounters a dilemma in effectively managing double standards in material procurement, quality control, and sanitary specifications. Adhering to the US standard undermines the cost advantages of products in loosely regulated markets, while adjusting the manufacturing processes to the lower standards in loosely regulated markets jeopardizes the image of the product in the US market. Installation of flexible manufacturing facilities can mitigate this dilemma, but it costs time and financial resources.

Rapid reconciliation of such routine differences exposes INVs with an opportunity to promptly adopt efficiency-enhancing routines (Autio et al., 2000 ), along with a great pressure upon absorption (Vermeulen \& Barkema, 2002). INVs internationalize earlier and faster than their counterparts to capture opportunities globally (Oviatt \& McDougall, 1994). In that process, INVs encounter rather different market entry barriers, governance quality, antitrust regulations, and policy uncertainties in different destination countries. The faster INVs expose themselves to institutional diversity, the more effectively they build long-lasting organizational routines in multi-institutional awareness along with their global footprint (Zhou \& Guillén, 2015).

Rapid expansion across institutions can also cause diseconomies of time compression (Vermeulen \& Barkema, 2002; Yamin \& Sinkovics, 2006), which substantially constrain INVs' resources to handle external shocks over a short period. As startup firms, INVs typically lack manufacturing experience, abundant cash flow, talent resources, proven technology, and market legitimacy (Mudambi \& Zahra, 2007). INV managers should maintain a delicate balance of resource allocation to different functions. The uncertainties during rapid expansion across institutional distance necessitate extra attention and resources, and therefore INV managers inevitably overstretch resources and encounter routine conflicts. For example, Xiaomi, a 
headline smartphone brand founded in China in 2010, internationalized quickly to the Indian market in 2014. However, the Delhi High Court banned its sales in India for several months upon Ericsson's plea of an alleged patent violation (Chatterjee \& Shih, 2014). Consequently, Xiaomi needed to significantly shift its strategic focus to building a stronger patent portfolio.

\section{Direction and Performance}

We examine the effects of export expansion direction on performance by focusing on two types of institutional environment from a sequential perspective, namely (a) entry barriers at national borders and (b) post-entry competition environment in destination markets. As trade liberalization lowers entry barriers, it substantially enhances market competition (Baggs \& Brander, 2006; Khandelwal et al., 2013; Melitz, 2003; Pavcnik, 2002). When manufacturers export their products from a less open country to a more open one (hereafter referred to as "upward export expansion" or "upward expansion," see Figure 1), they encounter lower import tariffs, fewer non-tariff barriers, shorter custom queuing, and consequently better profitability prospects (Baggs \& Brander, 2006). In an open destination market, buyers and local legislators hold a relatively unbiased attitude toward foreign products. Such a fair institutional environment helps accommodate foreign entrepreneurial manufacturing firms with relatively limited resources and capabilities. Influx of imported products from other origins creates intense competition

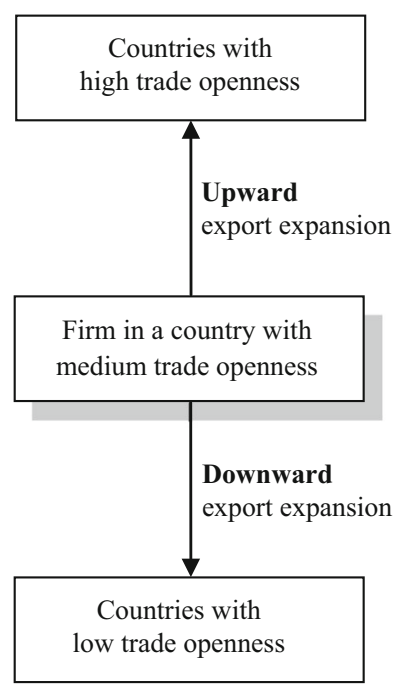

Figure 1 Upward and downward export expansions.
(Khandelwal et al., 2013). The competition propels the least efficient firms to quit the market (Melitz, 2003), and increases the overall productivity of the surviving firms (Pavcnik, 2002). The competition also expedites early organizational learning of INVs, rapidly develops their organizational routines for international markets, and helps achieve an "immunization" effect (Burke \& Hussel, 2013).

When entrepreneurial manufacturers export products from a more open country to a less open country (hereafter referred to as "downward export expansion" or "downward expansion," see Figure 1), they encounter higher tariffs that substantially increase entry costs and weaken price competitiveness of their products in the destination markets. Non-tariff entry barriers (e.g., import quotas, anti-dumping duties, countervailing duties) considerably aggravate operational risks and uncertainties too (Miller, Holmes, Feulner, Kim, Riley, \& Roberts, 2012). Because INVs have limited firm resources (Cavusgil \& Knight, 2015; Oviatt \& McDougall, 1994), they are usually not in an advantageous position to effectively overcome institutional constraints or fully accommodate negative shocks caused by high entry barriers and post-entry uncertainties.

\section{Upward Expansion Speed and Performance}

We now examine the joint effects of expansion speed and direction on INV performance (see Figure 2). The new construct of internationalization speed differs from the previous ones in the literature in two aspects. First, it incorporates institution as a new dimension of speed (apart from timing, scope, and intensity dimensions) and examines how fast a firm expands its export into institutionally different countries. Second, it adds direction to expansion speed and differentiates an upward expansion from a downward one. We first argue how learning advantages of newness outbalance diseconomies of time compression in the rapid upward expansion.

Rapidly expanding INVs inevitably encounter diseconomies of time compression in the competitive markets of more open destination countries. Countries with a high degree of trade freedom offer a relatively equal market access to exporters from any country of origin, resulting in intense local competition. Entrepreneurial manufacturers from emerging markets usually face insufficient competition from foreign rivals and enjoy relatively high levels of government protection (Edwards, 1993). Therefore, they are generally not as efficient as 


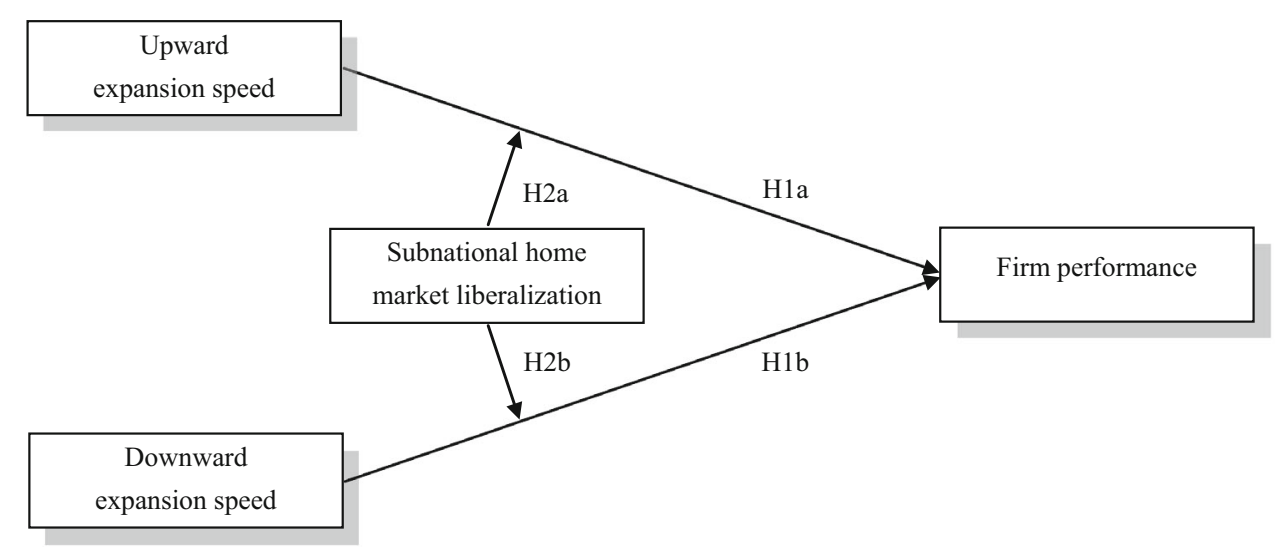

Figure 2 Impact of export expansion speeds on performance.

those firms from advanced economies (Khandelwal et al., 2013). Rapid expansion into liberalized markets exposes these entrepreneurial exporters to a competitive market environment, diverse customer needs, and reduced government protection within a short period (Baggs \& Brander, 2006). INVs face different types of rivals in various destination markets, and each type can adopt a different competition strategy, e.g., cost leadership or product differentiation. INVs are obliged to quickly examine their rivals' market strategies and reformulate corresponding reaction tactics. The difficulty lies in that each of these strategies necessitates different resource commitments, organizational designs, and market focuses. Attempts to rapidly accommodate these strategies may overstretch firm resources and management attention.

Nonetheless, INVs possess intrinsic learning advantages of newness that may effectively counterbalance the diseconomies of time compression. The first source of such advantages is the rapid reconstruction of pro-efficiency organizational routines for destination markets. International business stimulates firms to own new knowledge, routines, and practices suitable for an overseas location and its associated institutional environment (Qian, Khoury, Peng, \& Qian, 2010). Such institutional knowledge and routines may have an imprinting effect in subsequent international expansion to other destination locations (Cantwell, Dunning, \& Lundan, 2010). Entrepreneurially oriented, INVs are featured with ownership of innovative, proactive, and risk-taking organizational culture (Li et al., 2015; McDougall \& Oviatt, 2000). They may rapidly adapt their routines for their external environment in a new destination location through effective organizational learning (Autio et al., 2000). During rapid upward expansion, exposure to openness-enabled competition makes organizations more competitive and strategically alert (Barnett \& McKendrick, 2004; Burke \& Hussel, 2013). INVs are driven to design efficiencyenhancing culture that stimulates managers and employees to rapidly innovate or improve cost structure to attract and retain clients. The rapid formation of such culture constitutes a critical source of competitive edge, with which INVs may be better prepared for the competition in future export expansion.

The second source is the rapid "preview" of promarket institutions in an upward expansion to an open market (Dau, 2013) and resultant ownership of institutional skills suitable for a liberalized home market. INVs originating from emerging markets experience a shift from a centrally planned paradigm to a market-oriented one (Shinkle \& Kriauciunas, 2010; Zhou et al., 2006). During market liberalization, INVs need to rapidly downplay nonmarket strategies, and develop more market-based strategies such as product differentiation. Learning during rapid upward expansion enables firms to proactively acquire necessary skills and mindset (De Clercq, Sapienza, Yavuz, \& Zhou, 2012) that warrant improved home market performance vis-à-vis local rivals (Dau, 2013).

Moreover, a rapidly improved cost structure associated with lowered institutional barriers in a more open destination market considerably mitigates the diseconomies of time compression and strengthens the learning advantages of newness. 
Compared with less open target markets, rapid upward expansion into open target markets faces lower tariffs, as well as lower uncertainties involved in various forms of non-tariff barriers (WTO, 2012). ${ }^{2}$ Therefore, INVs may have a quick reduction in their marketing and maintenance costs, which is especially helpful if they rely on cost leadership. Equipped with such an ownership advantage of cost structure, INVs may relieve resource overstretches and routine conflicts caused by rapid organizational unlearning and learning. To summarize, the learning advantages of newness, through synthesis of ownership of entrepreneurial culture, ownership of institutional knowledge, and locational advantages, outweigh the diseconomies of time compression in rapid upward expansion.

Hypothesis 1a: Upward expansion speed positively affects the firm performance of INVs from emerging markets.

\section{Downward expansion speed and performance}

Rapid downward expansion causes strong diseconomies of time compression. Admittedly, knowledge from recent experience with the less open home market is easy to access, retrieve, and apply to the new destination market, and this knowledge may help exporters adapt to the less open destination market (Boehe, Qian, \& Peng, 2016). However, as INVs internationalize early and rapidly (Oviatt \& McDougall, 1994), such young firms originating from an emerging market do not usually possess as strong imprinting experience with their home market as more established firms. A moderate level of institutional distance between home (an emerging economy) and destination markets (also an emerging economy) does not guarantee a better financial performance, also because the institutional similarity could breed "carelessness" in deploying marketing resources (O'Grady \& Lane, 1996, pp. 324-325).

Rapidly expanding to a less open market leads to rapid restructuring of organizations to accommodate non-market routines and strategies. Consequently, it causes potential conflicts between old and new routines. With intrinsic ownership of entrepreneurial culture, INVs may rapidly divert a significant portion of management attention and financial resources to maintain strong foreign political connections (Rahaman, 2016), e.g., with chambers of commerce, business consulates, and custom officers in their target countries (Daniels et al., 2014). The routines built on such connections may suit a less open market, but they are sometimes counterproductive in more open home markets. INVs from emerging markets have acquired some market-based capabilities and have formed some organizational routines toward a market economy in their home countries (CuervoCazurra \& Dau, 2009) when they purchase inputs, recruit workers, and manufacture products at their home markets. Therefore, exporters with rapid downward expansion encounter challenges and overstretch resources in maintaining a balance between routines for more open home markets and those for less open destination markets.

Exporters rapidly expanding to less open destination markets have to quickly accommodate shocks from tariffs, non-tariff barriers, and bureaucracy in customs and border control agencies (Daniels et al., 2014). This change quickly exhausts financial resources and substantially constrains the adaptability of firms to new business practices oriented toward less open foreign markets. Different countries employ different measures to protect their indigenous industries, e.g., sanitary standards and import quotas. Exporters must adjust their routines in different directions to address different import barriers. For example, an exporter facing anti-dumping hazard in a foreign market needs to make its accounting system highly transparent for potential investigations. If that exporter happens to face high sanitary standards in another foreign market, it must also improve its procurement and manufacturing processes. Simultaneously and rapidly overcoming various tariff and non-tariff barriers is demanding for the financial capabilities and organizational flexibility of INVs, because these barriers reduce their cost competitiveness in destination markets, increase their operational uncertainty, and consequently jeopardize their financial performance (WTO, 2012). Rapid expansion to these countries leaves exporters with limited time and resources to compensate for losses caused by high operational costs. Rapidly exporting startups also face high post-entry hurdles over a short period of time, e.g., relatively inadequate market dynamism, high agency costs in distribution, and buyer hostility caused by a protectionist atmosphere (Edwards, 1993). In sum, the diseconomies of time compression outweigh the learning advantages of newness in rapid downward expansion. 
Hypothesis 1b: Downward expansion speed negatively affects the firm performance of INVs from emerging markets.

\section{Moderating Effects of Subnational Home Market Liberalization}

The market liberalization in the subnational origin of INVs strengthens the positive relationship between upward expansion speed and firm performance. First, home market liberalization leads to stronger market competition and enhances the learning advantages of newness during upward expansion. Home market liberalization minimizes state presence in competitive sectors in final products, such as electronics and textile (Park, Li, \& Tse, 2006). The strengthened competition forces the least efficient firms to exit (Khandelwal et al., 2013). It also stimulates the surviving firms to be more efficient (Barnett \& McKendrick, 2004) and capable of effectively leveraging the learning advantages of newness. New startups need to develop competition-related business routines early on to outperform their incumbent counterparts (Chang \& Wu, 2014). The familiarity with market competition, as well as ownership of entrepreneurial organizational culture, helps INVs to be able to quickly adapt themselves to the competitive environment in more open destination countries during rapid upward expansion. Moreover, INVs from a more liberalized home region are more likely to possess a stronger absorptive capacity in rapidly "previewing" and decoding the market institutions in more open destination countries (Dau, 2013) so that INVs may be better prepared for their business operations in the home market.

Second, home market liberalization saves operational costs and alleviates the diseconomies of time compression in upward expansion. Home market liberalization deregulates production factors, such as labor employment, bank loans, and land resources, so that they can be freely allocated and reallocated (World Bank, 2015). In particular, private entrepreneurial firms experience reduced ideological discrimination in obtaining bank loans in the subnational regions with abated state presence (Park et al., 2006). Reduced manufacturing and operational cost structure enables INVs to rapidly expand to more open countries. The export managers have a higher profit margin, more human resources to understand the business environment in those markets and formulate export routines for more open markets. ${ }^{3}$
Hypothesis 2a: The degree of subnational home market liberalization strengthens the positive relationship between upward export expansion speed and the firm performance of INVs from emerging markets.

The market liberalization in the subnational origin of INVs mitigates the negative relationship between downward expansion speed and firm performance. First, home market liberalization strengthens the strategic flexibility of INVs and consequently alleviates diseconomies of time compression during rapid downward expansion. The INVs may benefit from liberalization-stimulated competition (Burke \& Hussel, 2013) and become more productive (Chang \& $\mathrm{Wu}, 2014$ ) and more agile to accommodate market uncertainty. Such agility may be embodied in the managers' mindset and transferred to overseas markets. They help INVs assimilate the rapidly incoming new market information and adjust their market routines for the protectionist measures in the destination markets during rapid downward expansion. For example, when a destination country's government imposes an import quota, firms from a liberalized home market more swiftly contact the government or local import agency to apply for quota.

Second, INVs from a liberalized home origin may enjoy a lower cost structure (Park et al., 2006), which is critical in facilitating the INVs to cushion the cost pressure and diseconomies of time compression in rapid downward expansion. Due to the cost-saving effect of home market liberalization, the export managers of INVs may offer their price quote in a relatively advantageous position compared with their counterparts from a less liberalized subnational home origin. Furthermore, the export managers may also have a higher degree of financial freedom to adopt costly but necessary nonmarket strategies, e.g., developing connections with local customs agencies in the destination markets. Consequently, the relatively strong market return in rapid export expansion may grant export managers stronger power and confidence in transferring their best practices (Kostova, 1999) to future expansion. Therefore, during rapid downward expansion, home market liberalization helps INVs accommodate negative impact of trade barriers and adapt business routines.

Hypothesis 2b: The degree of subnational home market liberalization weakens the negative relationship between downward export 
expansion speed and the firm performance of INVs from emerging markets.

\section{METHOD}

\section{Sample}

We chose Chinese INVs in manufacturing sectors from 2000 to 2009 as the research setting. The sample period witnessed dynamic changes in both trade openness and home market liberalization since China's WTO accession in 2001. Nonetheless, the economy is featured with a startling regional disparity in market liberalization. The eastern region is traditionally more commercialized because of its proximity to the coast and logistic convenience for trade. Driven by the influx of foreign and private capital and economic development, the local governments in that region tend to hold a favorable attitude toward market liberalization (Zhou et al., 2006).

We consolidated two firm-level datasets. The first one is from the National Bureau of Statistics of China, which covers $90 \%$ of all Chinese manufacturing output. This dataset contains demographic and financial information on firms with independent legal and accounting status. The second one is a census dataset from the General Administration of Customs of China covering all Chinese exports. This dataset reports detailed yearly information on firm name, country of destination, and export value for every destination. Both datasets are annually updated, thus ensuring the absence of survival bias. As these two datasets employ different firm coding systems, we conducted firm matching using firm names instead of numerical identifiers (Khandelwal et al., 2013).

We confined the research sample to indigenous Chinese INVs and excluded all firms founded before the start year of the sample period, which is 2000. Thus, we ensured each firm began exporting during 2000-2009, and calculated the number of years the firms have conducted their export activities. We deleted state-owned enterprises and foreign-invested enterprises. In accordance with the international entrepreneurship literature, we only included firms that start exports within 6 years of inception (Coviello, 2015; Deng et al., 2017), and used 500 employees as the maximum sampling point (Lu \& Beamish, 2001; Sui \& Baum, 2014). The datasets do not provide information on whether a firm is affiliated to a large corporation or whether it owns subsidiaries. To purge the potential disturbance caused by such a group affiliation, we included firm-level control variables, such as productivity and firm size (in total assets), which are introduced in the variable section. Furthermore, we excluded firms with more than 250 employees in the first year of their business operation. We also excluded firms that never exported, but retained all observations (even without export in certain years) of firms that exported for at least 1 year during the entire sample period. Finally, to remove potential round-tripping exports and re-imports, we deleted four special destination markets, namely Hong Kong, Macau, Taiwan, and Chinese Mainland. All firms left in the sample exported their manufactured products to at least one overseas country during the sample period.

\section{Potential Endogeneity and Model Design}

We constructed an instrumental variable two-stage least squares (2SLS) model (Hashai, 2011) to control for the potential endogeneity in upward and downward export expansion speeds, since endogeneity is commonly observed in the relationship between international expansion and firm performance (Jean, Deng, Kim, \& Yuan, 2016; Mudambi \& Zahra, 2007; Sui \& Baum, 2014). ${ }^{4}$ Instrumental variables affect the dependent variable through their effects on the endogenous variable only (Hashai, 2011; Reeb, Sakakibara, \& Mahmood, 2012). The main regression of the 2SLS model on the effect of expansion speed on firm profitability is specified as follows:

$$
\begin{aligned}
\text { profitability }= & \alpha_{1}+\gamma_{1} \times \text { speed }+\gamma_{2} \times \text { speed } \\
& \times \text { moderator }+\gamma_{3} \times \text { moderator }+\boldsymbol{\beta} \\
& \times \text { exogenous }+\varepsilon_{1},
\end{aligned}
$$

where speed is the speed of export expansion. Speed is potentially an endogenous variable with two forms, namely upward expansion speed and downward expansion speed. They are specified in the variable section. To avoid the potential intertwining effects of multicollinearity with endogeneity, these two variables are entered separately. Exogenous refers to a vector of exogenous variables, and moderator represents home market liberalization. If an endogeneity test showed that speed correlated with the error term $\varepsilon_{1}$, then we ran the first stage of the 2SLS on speed. 


$$
\text { speed }=\alpha_{2}+\delta_{1} \times \text { exogenous }+\mu_{1} \times \text { instrument }_{1}+\varepsilon_{2},
$$

where instrument 1 denotes a vector of added instrumental variables. A critical identification condition is $\mu_{1} \neq 0$. That is, after separating the effects of exogenous variables, speed and instrument $_{1}$ remain correlated (Wooldridge, 2002b, pp. 473-74). If the endogeneity test showed that speed correlated with the error term $\varepsilon_{1}$, then its interaction term speed $\times$ moderator is correlated with $\varepsilon_{1}$, i.e., the interaction term is endogenous as well (Wooldridge, 2002a, pp. 121-22). Therefore, we need to estimate an additional first-stage 2SLS model on speed $\times$ moderator.

$$
\begin{aligned}
\text { speed } \times \text { moderator }= & \alpha_{3}+\boldsymbol{\delta}_{\mathbf{2}} \times \text { exogenous }+\boldsymbol{\mu}_{\mathbf{2}} \\
& \times \text { instrument }_{2}+\varepsilon_{3} .
\end{aligned}
$$

The fitted values of speed and speed $\times$ moderator obtained from Eqs. (2) and (3) were employed to replace the original values in Eq. (1) (the second stage of 2SLS).

\section{Variables}

\section{Dependent variable: profitability}

We measured profitability with firm-level rather than export project-level return on sales (ROS), which is calculated by net profit divided by total sales (Boehe et al., 2016; Chan et al., 2010), for the following reasons. First, export expansion speed fundamentally reshapes the organizational routines of INVs that usually internationalize early and rapidly. Exports represent an important portion of firm sales in the sample, averaging $41.7 \%$ for all observations and $58.2 \%$ in exporting years. This characteristic suggests that exports significantly affect overall corporate performance. Second, the literature on the relationship between export expansion speed and performance mainly focuses on corporate-level rather than project-level performance (Chang \& Rhee, 2011; Li et al., 2012; Mudambi \& Zahra, 2007; Vermeulen \& Barkema, 2002). Such a corporate-level construct and measure may fully capture the fundamental effect of rapid export expansion on firm routines, culture, survival, and performance. Third, a firm may deploy strategically low pricing in a specific country market in certain years. Thus, short-term volatility occurs in country-specific export and makes it less precise in reflecting the effect of rapid export expansion on firms' overall organizational routines and performance. Firm-level profitability uses global sales as the denominator and thus smoothens the effect of sales volatility in certain countries (Chan \& Makino, 2007).

\section{Independent variables: speeds of upward vs downward export expansion}

"Speed" refers to "the rate at which somebody or something moves or travels" (Turnbull et al., 2010). Vermeulen and Barkema (2002) measure internationalization speed with the number of overseas subsidiaries divided by the number of years spent on foreign expansion. However, we needed to incorporate country institutional profiles (Kostova, 1999) into this measure to cater for our study on speed across the distance of trade openness. In addition, a firm's international footprint covers multiple countries, and the repercussions from foreign markets vary depending on the country institutional profile and share of sales in each foreign market (Zhou \& Guillén, 2015).

Similar to Dau (2013), we dichotomized export expansion into upward and downward export expansions to refer to expansion to more open markets and less open markets, respectively. Upward expansion speed is the total sales share in a more open country of a firm (indexed by $i$ ) divided by the number of years spanning the period of the first export activity of the firm $\left(t_{0}\right)$ up to the current year $(t)$. We add one to $(t-$ $t_{0}$ ) to avoid zero denominators.

$$
\begin{gathered}
\text { upward expansion speed }_{i, t}=\frac{\sum_{j} s_{i, j, t}}{t-t_{0}+1}, \\
\text { if openness } s_{i, j, t}>\text { openness }_{i, \text { China }, t}, \\
\text { downward expansion speed }_{i, t}=\frac{\sum_{j} s_{i, j, t}}{t-t_{0}+1}, \\
\text { if openness } i_{i, j, t}<\text { openness }_{i, \text { China,t }},
\end{gathered}
$$

where $s_{i, j, t}$ is the share of export from the home country (China) to the $j$ th country in the total sales of the ith firm to all destinations (including home and export market sales) in year $t$, that is,

$$
s_{i, j, t}=\text { export }_{i, j, t} / \text { total sales }_{i, t} .
$$

To measure trade openness in the home country and in the export destination countries, we adopted an index from the Indices of Economic Freedom (Miller et al., 2012), which have been extensively employed in international business studies (e.g., Shinkle \& Kriauciunas, 2010). These indices comprise 10 dimensions, one of which is "trade 
freedom." The trade freedom index measures an economy's overall level of openness (both tariffs and non-tariff measures) for products imported from foreign countries. Therefore, adopting the trade freedom index is more appropriate than simply using tariffs to measure overall trade freedom. Country-level trade freedom also determines the degree of competition in destination markets (Baggs $\&$ Brander, 2006), thus potentially influencing postentry operational costs and firm performance with rapid export expansion. We did not employ a posteriori indicators of trade openness, e.g., ratio of total trade to gross domestic product (GDP), because such indicators are heavily dependent on economy size and structure and may not "capture the extent to which commercial policy impedes trade" (Edwards, 1993, p. 1390). The trade freedom index is a dynamic metric that reports a value on the trade openness of each country in each year.

Panel (a) in Figure 3 displays the significant variation of the average scores of trade freedom across different countries from 2000 to 2009. The minimum and maximum scores are 0 for North Korea and 85.9 for Singapore, respectively. In addition, trade liberalization reform after China's accession into the WTO caused the country's ranking to rise from the 135th place among 155 economies in 2000 to the 108th place among 173 economies covered by the Index in 2009. The medium position of China in the dimension of trade freedom justifies the appropriateness of China as a research setting, since Chinese manufacturers have abundant destination country options in both upward and downward expansions.

\section{Moderator: degree of home market liberalization}

We adopted a longitudinal provincial marketization index to measure the annual degree of liberalization of the market economies of 31 Chinese provinces from 2000 to 2009 (Fan, Wang, \& Zhu, 2011). The index indicates the liberalization of a province (not annual change), and its value exhibits a dynamic pattern of market liberalization over time. This institutional index consists of five pillars: (1) minimization of government intervention in the economy, (2) development of private sectors, (3) reduction of the protectionism for local firms, (4) development of the markets of production factors, and (5) protection of the interests of producers, intellectual properties, and consumer rights. Thus, the index concerns liberalization in the domestic market that forms the institutional environment of purchasing, manufacturing, recruiting, and innovation of INVs. The index is computed and updated annually using data from yearbooks, government reports, and survey data, among others. As market liberalization is an enduring process (Park et al., 2006), its effect on firm performance is mainly due to its degree and not to the marginal changes from year to year (CuervoCazurra \& Dau, 2009). The index has been extensively applied in the recent literature (e.g., Chang \& $\mathrm{Wu}, 2014$ ). Panel (b) in Figure 3 illustrates the variation in the degrees of market liberalization (as averaged over the sample period) across provinces. The lowest value is 0 for Tibet in 2000, whereas the highest is 11.8 for Zhejiang in 2009, and the scores exhibit a dynamic pattern in the sample period with a national average of 4.278 in 2000 and 7.335 in 2009.

\section{Instrumental variables}

We considered three instrumental variable candidates that are potentially the determinants of rapid export expansion. Instrumental variables should satisfy two requirements. The first is they significantly affect the two potentially endogenous speed variables in the first-stage regression. We adopted F-statistics in testing the coefficients of instrumental variables. The second requirement is instrumental variables should be uncorrelated with the error term in the second-stage regression of 2SLS estimation (Jean et al., 2016; Wooldridge, 2002a, pp. $83-84) .{ }^{5}$ For that requirement, we needed to use at least one instrumental variable more than endogenous variables (Wooldridge, 2002b, pp. 484-485), and then used Sargan over-identification test (Sargan, 1958).

The first instrumental variable candidate is firm age. This variable captures the learning experience of entrepreneurial firms (Chandra, 2017; Li et al., 2015). As new ventures mature, they build a particular set of capabilities to evaluate opportunities (Rahaman, 2016). In emerging markets, the export growth rate of nascent private firms declines when they age, become embedded in a home market institutional environment, and gain strong institutional legitimacy (Shinkle \& Kriauciunas, 2010). Firm age is calculated by deducting a firm's foundation year from its current observation year.

The second candidate is competition that captures the industrial competitive effects in the home country. While destination market competition directly affects export and corporate performance, home market competition only exerts a partial effect on firm performance directly, particularly 
(a) Scores of trade openness

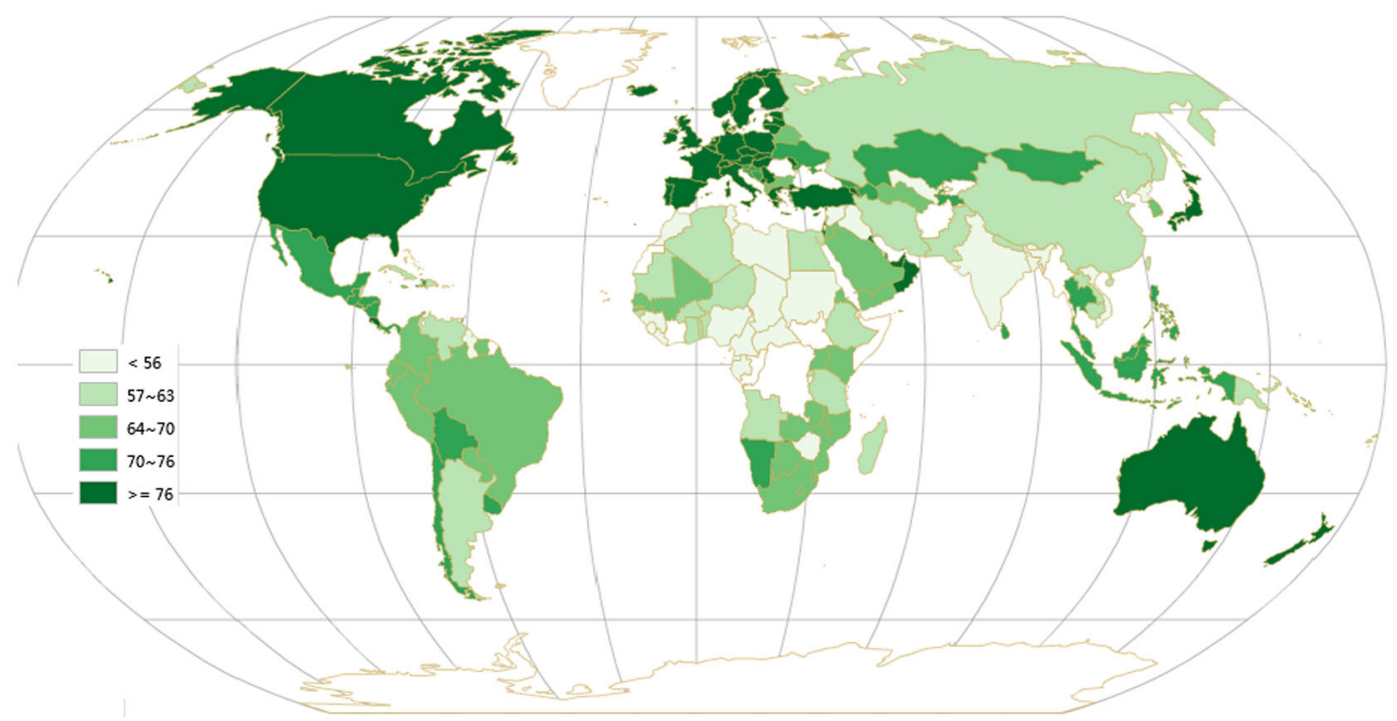

(b) Scores of market liberalization in subnational regions of China

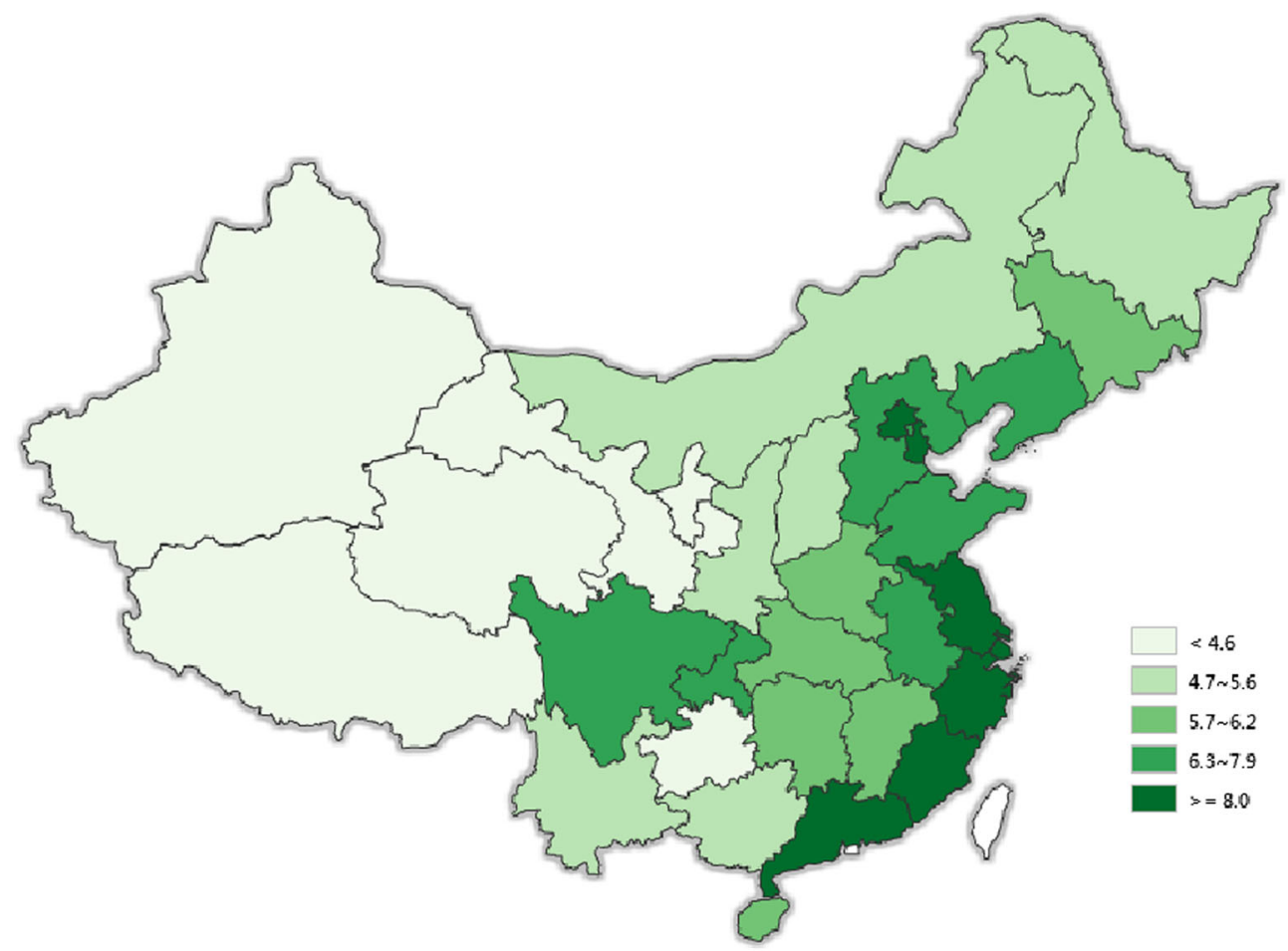

Figure 3 Trade openness and subnational market liberalization, 2000-2009. Notes Average scores for the 10 years are employed. Data source of panel (a) is the index of Miller et al. (2012) that covers 177 economies. The economies not covered in the index are shown in white in panel (a). Data source of panel (b) is the index of Fan et al. (2011) that covers 31 regions. Hong Kong, Macau, and Taiwan regions not covered in the index are shown in white in panel (b).

because of the high export intensity of the sample employed. Thus, home market competition is an appropriate candidate for instrumental variables.
We expected it to positively affect downward expansion speed in less open markets with weak market competition, that is, an escape from high 
home market competition (Xia, Ma, Lu, \& Yiu, 2014). Conversely, we expected a negative effect of competition on upward expansion speed in more open markets with strong market competition. Competition in a four-digit industry is measured by one minus the score of market concentration (Palmer \& Wiseman, 1999):

$$
\text { competition }_{t}=1-\sum_{i} h m s_{i, t}^{2},
$$

where $h m s_{i, t}$ denotes the ith firm's home market share in its industry in year $t$. A large variable indicates a low degree of industry concentration and high degree of competition among firms in that particular sector.

The third candidate is a firm's manufacturing productivity, which reflects the overall manufacturing efficiency in transforming all inputs (e.g., labor, machine, and intermediate materials) into final products (Chang \& Wu, 2014). Productivity can be explained by the previous experience of the executives, especially by their international experience (Cassiman \& Golovko, 2011; Le \& Kroll, 2017). Productivity plays a decisive role in determining the export propensity (Melitz, 2003). Productive firms are cost effective and can afford the entry costs incurred in initiating new export projects and expanding to overseas countries. Firm capabilities reflected in production efficiency also moderate the location decision during firm export expansion. Nonetheless, institutional barriers buffer the supporting effect of productivity and make highly productive new firms less able to maximize the benefit of high productivity (Chang \& Wu, 2014). When INV manufacturers engage in rapid downward expansion into less open countries with high entry costs and post-entry operational costs, the linkage between manufacturing productivity and ultimate financial performance will become substantially looser. Therefore, it is reasonable to include productivity as an instrumental variable for downward expansion speed. Productivity is calculated using an approach developed by Levinsohn and Petrin (2003).

\section{Multi-level control variables}

At the firm level, we used the share of new product sales in total sales to measure innovation (Cassiman \& Golovko, 2011). Innovativeness is one of the defining characteristics of international entrepreneurship (McDougall \& Oviatt, 2000). We included financial liability which is measured as the INV's long-term liabilities divided by total assets. It reflects the financial health and risk-taking attitude, as such an attitude has been one of the core features of international entrepreneurship too (McDougall \& Oviatt, 2000). The variable also reflects the firm's capability to acquire financing from banks and foster its overseas expansion. We measured firm size with the natural logarithm of total assets, since both tangible and intangible assets are important for the performance of INVs (Cavusgil \& Knight, 2015). We employed export intensity to capture the strategic importance of exports in the overall business portfolio of exporters (Lu \& Beamish, 2001), the experience and knowledge acquired from foreign markets (Chandra, 2017), as well as risk exposure during export expansion. Export intensity is measured by export value divided by total sales. Since the home country currency (Renminbi) experienced an appreciation in the sample period, we expected a export intensity negatively affects firm performance (Lu \& Beamish, 2001, p. 578).

We also constructed several variables to depict the characteristics of target countries. Number of countries measures the total number of foreign countries where a firm operates. It reflects the international experience (Chandra, 2017), as well as the challenges and opportunities associated with the extended span of control (Vermeulen \& Barkema, 2002). Geographic distance is measured by the weighted geographical distance, in $1000 \mathrm{~km}$, between an INV's home country (i.e., China) and its destination markets (Berry, Guillén, \& Zhou, 2010). The share of export to each destination market in total export is the weighing factor.

We included market size to control for the impact of the purchasing power and economic magnitude in destination markets (Chan \& Makino, 2007). Countries with a large market size usually attract significant international marketing efforts and contribute numerous sales to foreign exporters. Destination market size is measured by the population of its destination markets, weighted by the shares of export to destination markets in total export. We obtained country-level population data from the World Bank World Development Indicators.

The variable tariff is measured by the import tariff rates between an exporter's home country and its destination markets, weighted by the shares of export to destination markets. We obtained tariff data from the WTO (for its member countries) and the World Development Indicators (for other countries). This variable gauges the product-specific barriers to exports (WTO, 2013) and helps to control for the industry-level institutional environment in target countries. 
We included total export and total export growth to control for the potential disturbance caused by the magnitude and growth of total export from home to destination markets (Chan \& Makino, 2007). Exporters tend to export more to countries with a large import demand, and total export is measured by the weighted export value between an exporter's home country and its destination markets (in USD billions). The shares of export in destination markets are taken as the weighing factor. Similarly, total export growth is measured by the weighted export growth rates. Data on the country-level export are obtained from the United Nations Commodity Trade Database.

We also included several home country industrylevel control variables to capture industry idiosyncratic factors. First, we included export tax rebate rates at the six-digit product level. Data are obtained from the General Administration of Customs of China. As a firm may export multiple products in the same year, we calculated the weighted tax rebate rates for each firm in every year with the export share of each product as the weight. It reflects both the degree of government support and policy dependence of the focal firm. Second, we included the dummy variable high-tech industry. Consistent with the widely adopted Organization for Economic Co-operation and Development (OECD) approach using R\&D intensity as a criterion to define high-technology sectors (OECD, 2011), National Bureau of Statistics in China categorizes 59 out of 480 sectors into high-technology ones, such as optical fiber manufacturing. Third, we included variables industry dynamism and industry growth. We first regressed the logarithm of industrylevel sales of each four-digit industry in China in the preceding 5 years against the year variable. Then, industry dynamism is obtained with the antilogs of the standard errors (Keats \& Hitt, 1988). Industry growth is measured by the growth rate of all domestic sales in each of the sectors in China in a year (Keats \& Hitt, 1988). Fourth, we included INV density. Density of similar firms strengthens the legitimacy of similar entities but also intensifies the potential competition among them for similar resources in a local environment (Barnett \& McKendrick, 2004). We measured INV density with the number of INVs in each provinceindustry-year group to differentiate from the instrumental variable industry competition.

Finally, we included a single entry of the moderator as a control variable, namely home market liberalization (Chang \& Wu, 2014; Park et al., 2006).
It has both enabling and disabling effects on INVs. On one hand, home market liberalization lowers institutional barriers, offers entrepreneurial firms relatively equal market opportunities, enhances the cost advantages of firms, and stimulates firms to be more agile and productive. On the other hand, home market liberalization invites stronger market competition that may squeeze the profit margins of home market sales and crowd out the least efficient firms (Chang \& Wu, 2014, p. 1115) and firms overly dependent on the home sales. Therefore, the net direct effect of home market liberalization on firm performance is mixed and is subject to an empirical test. We included 9 year dummy variables, and lagged all independent variables by a year.

\section{RESULT}

\section{Baseline Result}

Table 1 reports the descriptive analysis and the correlation coefficients of the major variables. The coefficients are lower than 0.33 . The average variance inflation factor (VIF) value in models is below 1.5 , and all VIF values of the variables involved in the interaction effects are below 2.6. The low VIF values remove the concern of multicollinearity.

Table 2 presents the main empirical findings obtained from the second-stage model of 2SLS estimation. ${ }^{6}$ Model 1 includes upward expansion speed as a potential endogenous variable. Durbin $\chi^{2}$ test confirms the endogeneity of upward expansion speed, and the F-statistics reports the joint significance of the coefficients on the instrumental variables in the first-stage regression after separating the effect of exogenous variables. F-test suggests that the included instrumental variables (age and competition) are highly correlated with the endogenous variable. The Sargan test $(0.842)$ on overidentification restriction justifies the validity of instrumental variables (Sargan, 1958). Therefore, H1a is supported. Model 2 includes downward expansion speed as the main explanatory variable, and both the F-test and Sargan test support competition and productivity as valid instrumental variables. Downward expansion speed has a significantly negative coefficient, thus supporting H1b.

To test the moderating effect of home market liberalization, we included its interaction term with upward expansion speed in Model 3. Following Aiken and West (1991), we mean-centered the two speed variables and the moderator to avoid the potential multicollinearity caused by the interaction terms. 
Table 1 Descriptive statistics and correlation coefficients

\begin{tabular}{|c|c|c|c|c|c|c|c|c|c|c|c|}
\hline Variable & 1 & 2 & 3 & 4 & 5 & 6 & 7 & 8 & 9 & 10 & 11 \\
\hline 1. Profitability & 1.00 & & & & & & & & & & \\
\hline 2. Innovation & 0.05 & 1.00 & & & & & & & & & \\
\hline 3. Financial liability & -0.02 & 0.01 & 1.00 & & & & & & & & \\
\hline 4. Size & 0.05 & 0.03 & 0.10 & 1.00 & & & & & & & \\
\hline 5. Export intensity & -0.10 & 0.07 & -0.05 & -0.12 & 1.00 & & & & & & \\
\hline 6. Age & -0.03 & -0.10 & 0.00 & 0.20 & 0.04 & 1.00 & & & & & \\
\hline 7. Productivity & 0.11 & -0.04 & 0.03 & 0.15 & -0.11 & 0.04 & 1.00 & & & & \\
\hline 8. Competition & -0.01 & -0.04 & 0.01 & -0.02 & 0.01 & 0.02 & 0.06 & 1.00 & & & \\
\hline 9. No. of countries & -0.02 & 0.03 & -0.03 & 0.11 & 0.25 & 0.08 & 0.00 & -0.08 & 1.00 & & \\
\hline 10. Geographic distance & -0.02 & 0.03 & -0.01 & -0.03 & 0.04 & -0.03 & -0.03 & -0.02 & 0.14 & 1.00 & \\
\hline 11. Tariff & -0.02 & 0.00 & 0.00 & -0.01 & 0.00 & -0.04 & 0.00 & 0.03 & 0.02 & 0.01 & 1.00 \\
\hline 12. Market size & 0.00 & 0.02 & 0.00 & 0.02 & -0.02 & -0.03 & 0.00 & 0.00 & -0.04 & 0.11 & 0.06 \\
\hline 13. Total export & 0.02 & -0.02 & 0.01 & -0.02 & -0.11 & -0.03 & 0.02 & 0.01 & -0.25 & 0.12 & -0.08 \\
\hline 14. Total export growth & -0.01 & 0.00 & 0.03 & -0.04 & -0.16 & -0.09 & -0.02 & 0.02 & -0.32 & 0.03 & 0.10 \\
\hline 15. Tax rebate & 0.00 & 0.06 & -0.02 & 0.00 & 0.05 & 0.01 & -0.13 & -0.09 & 0.08 & 0.06 & 0.00 \\
\hline 16. High-tech industry & 0.05 & 0.08 & 0.00 & 0.06 & -0.05 & 0.04 & -0.10 & -0.13 & 0.01 & 0.01 & -0.06 \\
\hline 17. Industry dynamism & 0.00 & 0.05 & 0.01 & 0.03 & -0.09 & -0.10 & 0.03 & 0.07 & 0.01 & 0.02 & 0.04 \\
\hline 18. Industry growth & 0.02 & 0.00 & 0.01 & -0.07 & 0.00 & -0.05 & 0.03 & -0.03 & 0.01 & 0.00 & -0.03 \\
\hline 19. INV density & -0.03 & -0.05 & -0.03 & -0.02 & 0.03 & 0.05 & 0.00 & 0.22 & -0.02 & -0.01 & 0.05 \\
\hline 20. Home market liberalization & -0.07 & -0.01 & -0.07 & -0.03 & 0.18 & 0.12 & -0.18 & -0.01 & 0.15 & 0.05 & -0.04 \\
\hline 21. Upward expansion speed & -0.05 & 0.06 & -0.03 & -0.21 & 0.29 & -0.22 & -0.14 & -0.01 & 0.22 & 0.09 & -0.06 \\
\hline 22. Downward expansion speed & -0.02 & 0.01 & -0.02 & -0.09 & 0.10 & -0.11 & -0.06 & -0.01 & 0.11 & -0.12 & 0.17 \\
\hline Mean & 0.03 & 0.05 & 0.03 & 9.68 & 0.42 & 4.32 & 177.79 & 0.99 & 7.25 & 0.67 & 0.09 \\
\hline SD & 0.07 & 0.19 & 0.09 & 1.02 & 0.40 & 1.98 & 223.84 & 0.03 & 7.24 & 0.29 & 0.12 \\
\hline Variable & 12 & 13 & 14 & 15 & 16 & 17 & 18 & 19 & 20 & 21 & 22 \\
\hline
\end{tabular}

1. Profitability

2. Innovation

3. Financial liability

4. Size

5. Export intensity

6. Age

7. Productivity

8. Competition

9. No. of countries

10. Geographic distance

11. Tariff

12. Market size $\quad 1.00$

13. Total export $\quad 0.22$

14. Total export growth $\quad 0.03$

15. Tax rebate

16. High-tech industry

17. Industry dynamism

18. Industry growth

19. INV density

0.04

0.04

$0.01-0.01$

$\begin{array}{rrrrr}0.05 & -0.01 & 0.06 & 0.05 & 0.02\end{array}$

$\begin{array}{rrrrr}-0.01 & 0.03 & 0.02 & -0.16 & -0.05\end{array}$

$\begin{array}{lllll}-0.02 & -0.01 & -0.01 & 0.10 & -0.12\end{array}$

20. Home market liberalization

21. Upward expansion speed

22. Downward expansion speed Mean

$-0.01$

$\begin{array}{llll}-0.12 & -0.19 & -0.01 & -0.04\end{array}$

$\begin{array}{lllll}0.08 & -0.09 & -0.06 & 0.04 & -0.02\end{array}$

$\begin{array}{rrrrrr}1.00 & & & & & \\ 0.00 & 1.00 & & & & \\ 0.21 & -0.10 & 1.00 & & & \\ -0.01 & 0.01 & 0.24 & 1.00 & & \\ -0.01 & 0.06 & 0.00 & 0.05 & 1.00 & \\ 0.03 & -0.04 & 0.00 & -0.01 & 0.05 & 1.00 \\ 1.00 & 0.35 & 0.20 & 9.72 & 0.13 & 0.02 \\ 0.00 & 0.17 & 0.32 & 1.63 & 0.17 & 0.07\end{array}$

$\left.\begin{array}{lllll}0.01 & 0.04 & 0.11 & 0.04 & 0.24\end{array}\right]$ 
Table 2 Regression results

\begin{tabular}{|c|c|c|c|c|c|}
\hline Variables & Variable level & Model 1 & Model 2 & Model 3 & Model 4 \\
\hline Intercept & & $\begin{array}{l}1.528 \\
(2.605)\end{array}$ & $\begin{array}{l}6.411 \\
(5.803)\end{array}$ & $\begin{array}{l}2.549 \\
(2.493)\end{array}$ & $\begin{array}{l}-3.262 \\
(7.504)\end{array}$ \\
\hline Innovation & Firm & $\begin{array}{l}0.016^{* * *} \\
(0.003)\end{array}$ & $\begin{array}{l}0.016^{* *} \\
(0.007)\end{array}$ & $\begin{array}{l}0.015^{\star * *} \\
(0.003)\end{array}$ & $\begin{array}{l}-0.007 \\
(0.010)\end{array}$ \\
\hline Financial liability & Firm & $\begin{array}{l}-0.016^{* * *} \\
(0.006)\end{array}$ & $\begin{array}{l}-0.020 \\
(0.014)\end{array}$ & $\begin{array}{l}-0.019^{\star * *} \\
(0.005)\end{array}$ & $\begin{array}{l}-0.040^{* *} \\
(0.018)\end{array}$ \\
\hline Size & Firm & $\begin{array}{l}0.004^{\star * *} \\
(0.001)\end{array}$ & $\begin{array}{l}-0.010^{\star \star \star} \\
(0.003)\end{array}$ & $\begin{array}{l}0.003^{\star \star \star *} \\
(0.001)\end{array}$ & $\begin{array}{l}0.002 \\
(0.002)\end{array}$ \\
\hline Export intensity & Firm & $\begin{array}{l}-0.017^{\star * *} \\
(0.001)\end{array}$ & $\begin{array}{l}-0.004 \\
(0.004)\end{array}$ & $\begin{array}{l}-0.018^{* * *} \\
(0.001)\end{array}$ & $\begin{array}{l}-0.012^{* *} \\
(0.005)\end{array}$ \\
\hline No. of countries & Target country & $\begin{array}{l}0.000 \\
(0.000)\end{array}$ & $\begin{array}{l}0.002^{\star * \star} \\
(0.000)\end{array}$ & $\begin{array}{l}0.000 \\
(0.000)\end{array}$ & $\begin{array}{l}0.000 \\
(0.000)\end{array}$ \\
\hline Geographic distance & Target country & $\begin{array}{l}-0.003 \\
(0.002)\end{array}$ & $\begin{array}{l}-0.064^{\star * *} \\
(0.013)\end{array}$ & $\begin{array}{l}-0.003 \\
(0.002)\end{array}$ & $\begin{array}{l}-0.004 \\
(0.006)\end{array}$ \\
\hline Market size & Target country & $\begin{array}{l}-0.025 \\
(0.045)\end{array}$ & $\begin{array}{l}0.811^{\star * *} \\
(0.196)\end{array}$ & $\begin{array}{l}0.002 \\
(0.044)\end{array}$ & $\begin{array}{l}0.077 \\
(0.141)\end{array}$ \\
\hline Tariff & Target country & $\begin{array}{l}-0.000 \\
(0.004)\end{array}$ & $\begin{array}{l}0.101^{* * *} \\
(0.022)\end{array}$ & $\begin{array}{l}-0.000 \\
(0.004)\end{array}$ & $\begin{array}{l}0.002 \\
(0.013)\end{array}$ \\
\hline Total export & Target country & $\begin{array}{l}0.023 \\
(0.015)\end{array}$ & $\begin{array}{l}-0.005 \\
(0.037)\end{array}$ & $\begin{array}{l}0.013 \\
(0.014)\end{array}$ & $\begin{array}{l}0.084^{*} \\
(0.049)\end{array}$ \\
\hline Total export growth & Target country & $\begin{array}{l}0.037^{* *} \\
(0.015)\end{array}$ & $\begin{array}{l}-0.080^{*} \\
(0.043)\end{array}$ & $\begin{array}{l}0.032^{* *} \\
(0.014)\end{array}$ & $\begin{array}{l}0.052 \\
(0.049)\end{array}$ \\
\hline Tax rebate & Home industry & $\begin{array}{l}-0.006 \\
(0.005)\end{array}$ & $\begin{array}{l}-0.015 \\
(0.012)\end{array}$ & $\begin{array}{l}-0.008 \\
(0.005)\end{array}$ & $\begin{array}{l}-0.032^{* *} \\
(0.016)\end{array}$ \\
\hline High-tech industry & Home industry & $\begin{array}{l}0.012^{\star * *} \\
(0.002)\end{array}$ & $\begin{array}{l}0.007 \\
(0.005)\end{array}$ & $\begin{array}{l}0.011^{* * *} \\
(0.002)\end{array}$ & $\begin{array}{l}0.006 \\
(0.007)\end{array}$ \\
\hline Industry dynamism & Home industry & $\begin{array}{l}-1.517 \\
(2.603)\end{array}$ & $\begin{array}{l}-6.205 \\
(5.800)\end{array}$ & $\begin{array}{l}-2.509 \\
(2.492)\end{array}$ & $\begin{array}{l}3.547 \\
(7.515)\end{array}$ \\
\hline Industry growth & Home industry & $\begin{array}{l}0.004^{* * *} \\
(0.001)\end{array}$ & $\begin{array}{l}0.002 \\
(0.003)\end{array}$ & $\begin{array}{l}0.003^{* *} \\
(0.001)\end{array}$ & $\begin{array}{l}0.000 \\
(0.004)\end{array}$ \\
\hline INV density & Home industry \& region & $\begin{array}{l}-0.001 \\
(0.002)\end{array}$ & $\begin{array}{l}0.004 \\
(0.004)\end{array}$ & $\begin{array}{l}-0.001 \\
(0.002)\end{array}$ & $\begin{array}{l}-0.013^{* *} \\
(0.006)\end{array}$ \\
\hline Home market liberalization & Home region & $\begin{array}{l}-0.002^{* * *} \\
(0.000)\end{array}$ & $\begin{array}{l}-0.005^{* * *} \\
(0.001)\end{array}$ & $\begin{array}{l}-0.005^{\star * *} \\
(0.001)\end{array}$ & $\begin{array}{l}-0.029^{* * *} \\
(0.006)\end{array}$ \\
\hline Year dummy variables & & Included & Included & Included & Included \\
\hline H1a: Upward expansion speed & & $\begin{array}{l}0.022^{* * *} \\
(0.006)\end{array}$ & & $\begin{array}{l}0.011^{* *} \\
(0.006)\end{array}$ & \\
\hline H1b: Downward expansion speed & & & $\begin{array}{l}-1.391^{\star * *} \\
(0.268)\end{array}$ & & $\begin{array}{l}-4.154^{\star * *} \\
(0.997)\end{array}$ \\
\hline $\begin{array}{l}\text { H2a: Upward expansion speed } \\
\times \text { Home market liberalization }\end{array}$ & & & & $\begin{array}{l}0.016^{* * *} \\
(0.005)\end{array}$ & \\
\hline $\begin{array}{l}\text { H2b: Downward expansion speed } \\
\times \text { Home market liberalization }\end{array}$ & & & & & $\begin{array}{l}3.139 * * * \\
(0.726)\end{array}$ \\
\hline Durbin $\chi^{2}$ (endogeneity test) & & $14.954^{\star * *}$ & $172.619 * * *$ & $21.498^{* * *}$ & $196.693^{* * *}$ \\
\hline F-statistics (first stage) & & $36.166^{\star * *}$ & $15.792^{\star * *}$ & $\begin{array}{l}27.000^{* * *} \\
17.412^{* * *}\end{array}$ & $\begin{array}{l}49.874^{\star * *} \\
21.708^{\star * *}\end{array}$ \\
\hline Sargan $p$ value & & 0.842 & 0.600 & 0.732 & 0.577 \\
\hline
\end{tabular}

Note Standard errors in parentheses. ${ }^{*}$ if $p<0.1,{ }^{* *}$ if $p<0.05, * * *$ if $p<0.01$. In Models 3 and 4, we report two F-test values as two sets of first-stage regressions correspond to two endogenous variables, respectively, i.e. speed and its interaction with home market liberalization.

Upward expansion speed is potentially correlated with the error term, as is the interaction term upward expansion speed $\times$ home market liberalization. Therefore, the interaction term is an additional endogenous variable. To implement the Sargan test on two endogenous variables, we must include at least three instrumental variables. Following Wooldridge (2002a, pp. 121-22), we added the 
interaction term between the instrumental variable age and the moderating variable home market liberalization as an additional instrumental variable (age $\times$ home market liberalization). Again, the Durbin endogeneity test, F-test, and Sargan test all justify our model design. The interaction between has a significantly positive sign, thus supporting $\mathrm{H} 2 \mathrm{a}$.

Finally, we added an interaction term between downward expansion speed and home market liberalization in Model 4. Consequently, there are now two endogenous variables (downward expansion speed and downward expansion speed $\times$ home market liberalization). We added the interaction term between an instrumental variable competition and the moderating variable home market liberalization as an additional instrumental variable (competition $\times$ home market liberalization). The coefficient of downward expansion speed in Model 4 is negative, consistently supporting H1b. The coefficient of the interaction term in Model 4 is positive, suggesting that home market liberalization mitigates the negative relationship between downward expansion speed and performance, which supports $\mathrm{H} 2 \mathrm{~b}{ }^{7}$

\section{Robustness Tests}

We conducted various sets of tests using different models and measures to ensure the robustness of our findings. ${ }^{8}$ First, we employed four alternative indicators of institution that affect exports, because it potentially overlooks the complexity and ambiguity in institutional forms to uniquely position countries on a linear scale of trade openness. Following the international business literature that emphasizes the influence of economic development level on institutions (Boehe et al., 2016; Cuervo-Cazurra \& Genc, 2008; Tsang \& Yip, 2007), we first used the worldwide median level of GDP per capita as the cutoff point to dichotomize all destination economies into more open versus less open economies. Following Shinkle and Kriauciunas (2010), we also measured the export-pertinent institutional profiles of China and destination countries using the average of three sub-indices of the Indices of Economic Freedom, that is, trade freedom, financial freedom, and freedom from corruption. We also underscored the effects of governance environment on exporting using the World Bank's Worldwide Governance Indicators (Kaufmann \& Kraay, 2016). With China's score as the cutoff point, we grouped the destination countries of export expansion into upward versus downward ones. Finally, with the International
Monetary Fund's standard, which includes 35 "advanced economies" and 24 "emerging and developing economies" (International Monetary Fund, 2015), we labeled export expansion to the former cohort as "upward" and the latter as "downward." The empirical results of the four alternatives of institutional dichotomy all support the hypotheses.

Second, we modified the speed measure by incorporating the exact institution distance in Eqs. (4) and (5) and using the speed to precisely gauge the net effect of potential learning advantages of newness regarding diseconomies of time compression. ${ }^{9}$ We found the average institutional distance in the dimension of trade openness between China and more open markets decreases and even becomes smaller than that between China and less open markets after 2005. This fact suggests that the institutional distance between China and downward destinations is non-trivial. We constructed a firm-level weighted distance measure similar to that of Zhou and Guillén (2015). Speed is measured as weighted distance divided by time. Specifically, speed of firm export expansion in the $t$ th year is measured by the weighted distance in trade openness between China and all export destinations (collectively denoted by $j$ ) of the $i$ th INV divided by the export tenure since the firm's first export project in year $t_{0}$

$$
\begin{aligned}
& \text { upward expansion speed } \text { sp }_{i, t} \\
& =\frac{\sum_{j}\left(\left(\text { openness }_{i, j, t}-\text { openness }_{i, \text { China }, t}\right) \times s_{i, j, t}\right)}{t-t_{0}+1}, \\
& \quad \text { if } \text { openness }_{i, j, t}>\text { openness }_{i, \text { China }, t},
\end{aligned}
$$

$$
\begin{aligned}
& \text { downward expansion speed }_{i, t} \\
& =\frac{\sum_{j}\left(\left(\text { openness }_{i, \text { China }, t}-\text { openness }_{i, j, t}\right) \times s_{i, j, t}\right)}{t-t_{0}+1}, \\
& \quad \text { if } \text { openness }_{i, j, t}<\text { openness }_{i, \text { China }, t} .
\end{aligned}
$$

The variables openness $i_{i, j, t}$ and openness $s_{i, \text { China, } t}$ are the same as those use in Eqs. (4) and (5). ${ }^{10}$ Empirical results consistently support all the hypotheses. We used Worldwide Governance Indicators to replace the Index of Economic Freedom in measuring country-level openness and obtain similar results. Finally, we modified the speed variables to accommodate the recency effect in institutional exposure (Perkins, 2014). Prior to the INV's expansion into foreign markets, its organizational routine 
is affected by the firm's exposure to the home market institutions. Given the firm's recent institutional experience at home (emerging markets), the less open countries are more familiar to that at home. Such an institutional similarity triggers the entry into similar markets (Zhou \& Guillén, 2015) and brings desirable performance (Perkins, 2014). Moreover, knowledge from recent experience is easy to access, retrieve, and apply. We changed the value of openness ${ }_{i, \text { China, }}$ in Eqs. (4) and (5) to the average value of the past 3 years to capture the imprinting effects of the recent institutional exposure, i.e., openness $i_{i, \text { China }, t}=$ openness $_{i, \text { China }, t}+$ openness $s_{i, \text { China }, t-1}+$ openness $_{i, \text { China }, t-2) / 3}$. We also considered the "depreciation" effect of a previous experience, i.e., openness ${ }_{i, \text { China }, t}=(0.5 \times$ openness $_{i, \text { China }, t}+0.3 \times$ openness $_{i, \text { China }, t-1}+0.2 \times$ open- $^{-}$ $n_{\text {ess }}$, China,t-2). Both measures support all the hypotheses.

Third, we employed new speed variables constructed based on entropy. Entropy measure accounts for both the scope of target markets from which a firm obtains sales (i.e., geographic spread) and the relative importance of each country to total sales (i.e., geographic concentration) (Qian et al., 2010). Specifically, the speed of firm export expansion is the international market entropy of the $i$ th exporter, divided by one plus the tenure in export market $\left(t-t_{0}\right)$ :

upward expansion speed sp $_{i, t}=\frac{\sum_{j} s_{i, j, t} \ln \left(1 / s_{i, j, t}\right)}{t-t_{0}+1}$,

if openness $s_{i, j, t}>$ openness $_{i, \text { China }, t}$,

downward expansion speed si,t $=\frac{\sum_{j} s_{i, j, t} \ln \left(1 / s_{i, j, t}\right)}{t-t_{0}+1}$,

if openness $i_{i, j, t}<$ openness $_{i, \text { China, },}$.

The empirical results consistently support all the hypotheses.

Fourth, we performed three independent robustness tests on the firm size in sampling. We first used 250 employees as the sampling threshold by following the OECD standard (OECD, 2016, p. 21). Then, we lowered the maximum number to 100 employees in the entire sample period ( $\mathrm{Li}$ et al., 2015). Finally, we lowered the ceiling to a maximum of 100 employees in the first year but set no upper limit for subsequent employment growth to avoid "growth penalty." All three tests obtained consistent results.
Fifth, we used different firm ages in sampling. As the main arguments of the study are based on the notion of learning advantages of newness, using older firms is logical in contrast with INVs to provide strong evidence supporting the theory. We constructed various new samples of older (more established) firms. When we used firms that were founded during 2000-2009 but confined the cohort to firms older than 6 years old, the effects of both upward and downward expansion speeds become insignificant. This finding suggests weaker learning advantages of newness in upward expansion and weaker diseconomies of time compression (possibly due to the recency effect) in the downward expansion of older firms. When we constructed a different sample of even older firms that were founded before 2000, the upward expansion speed has an insignificant or even negative effect on firm profitability. The effects of downward speed become less negative, and the effects even become positive in rare cases (e.g., when number of destination countries equals one and firm age is larger than 10), which is consistent with the findings in the rather limited literature suggesting the positive effects of emerging economy firms expanding into similar (emerging) economies (Boehe et al., 2016; CuervoCazurra \& Genc, 2008). To summarize, the new results based on older firms exhibit a clear and common pattern; that is, the learning advantages of newness and diseconomies of time compression fade out when firms become older. The contrast between INVs and old firms corroborates the validity of our hypotheses on INVs.

Sixth, we employed a generalized method of moment approach in the instrumental variable regression. Robust estimates have also been obtained after controlling for clustering on each firm, i.e., within-firm correlation among observations. The results support all the hypotheses. Finally, considering the manufacturing nature of the sample firms and the constraining effects of total assets in firm expansion, we employed $R O A$ to replace $R O S$. We calculated $R O A$ with net profit divided by total assets (Lu \& Beamish, 2001). Although the correlation coefficient between ROA and manufacturing productivity is 0.29 , the Sargan test shows that the correlation between productivity and the error terms of $R O A$ regressions is trivial, justifying productivity as a valid instrumental variable. The results consistently support all the hypotheses. 


\section{DISCUSSION}

\section{Contributions}

From a locational perspective, this study provides four theoretical contributions to the literature on institutional theory and INVs. First, the study incorporates an institutional dimension into the speed of INV internationalization. Cultural or institutional difference has been an indispensable and fundamental factor to consider the process model of internationalization (Johanson \& Vahlne, 1977). However, the literature on the speed of internationalization has in general only examined the dimensions in timing, country scope, and foreign commitment (Kuivalainen et al., 2007; Oviatt \& McDougall, 2005). Institutional dimension helps to broaden the lens to examine the speed of internationalization, and to highlight the rich institutional contexts during the internationalization process.

Second, the research extends the widely accepted norm in analyzing supranational difference between locations, which usually does not account for direction or asymmetry (Zaheer et al., 2012). Based on the rather limited literature addressing the direction of internationalization (Dau, 2013; Tsang \& Yip, 2007), the current research goes a step further and incorporates the direction into the speed of international expansion. It explicitly divides rapid export expansion into upward and downward ones from an institutional perspective and reveals the fundamental differences in their effects.

Third, this research complements the literature that has overly stressed the negative effects of institutional distance and associated concepts on organizations (Stahl et al., 2016), and it discloses sheer contrast among rapid export expansion toward different destination locations. We suggest some scenarios under which seemingly disadvantageous startup firms from emerging markets may overcompensate their weakness and enjoy financial gains. The findings show the value of adjusting our analytical mindset and identifying the potential benefits of some constructs that have been conventionally regarded negative.

Fourth, this study both zooms in and zooms out the analytical lens along the location-related institutional axis, examines the joint effect of institutions involved in supranational directions and subnational origins on firm performance, and advances institutional theory. Different aspects of institutions may exert different effects on corporate decisions at different organizational levels in international business (Chan \& Makino, 2007). In particular, this study goes beyond the conventional constructs of country of origin and scrutinizes the roles of subnational region of origin in international business (Kirkman et al., 2017). The findings suggest the importance of research on integrating different dimensions of institutions (Holmes et al., 2013).

\section{Limitations and Future Research}

Admittedly, our research setting of entrepreneurial manufacturers in a trade openness context does not represent all international business scenarios. The generalizability of our findings remains subject to conceptual reexaminations and empirical tests in different contexts. First, future studies can investigate how broader dimensions (e.g., historical and cultural) of institutional distance (Kirkman et al., 2017; Sojli \& Tham, 2017), apart from trade openness and the ones used in the robustness tests, affect the performance of rapid export expansion. Second, subnational dimensions of institutions in destination countries should be considered and combined too when one extends the sample from exporters to MNEs. Compared with exporters, MNE subsidiaries in overseas markets are less affected by the home country institutions (Zhou \& Guillén, 2015). Geographic variations of institutions in target markets are crucial for local manufacturing, recruiting, and innovation as well as the isomorphism strategies of MNE subsidiaries (Chan et al., 2010; Ma et al., 2013b). Third, due to data limitation, the study cannot measure individual-level innovative, proactive, and risk-taking attributes of the executives of INVs (McDougall \& Oviatt, 2000; Oviatt \& McDougall, 2005). We have included some firm-level variables such as innovation, financial leverage, and productivity to control for such characteristics. Nevertheless, future studies may explore the roles of the individual-level factors ( $\mathrm{Li}$ et al., 2015) in the relationship between rapid export expansion and performance. Finally, the two essential concepts in hypotheses, namely learning advantages of newness and diseconomies of time compression, still lack precise empirical operationalization, and future research may develop concrete measurement.

\section{Implications}

This study offers important insights for managers in INVs. First, if entrepreneurs plan to export their products to multiple institutionally different 
countries in a relatively short period, they should consider the degree of trade openness in the destination locations. Rapid upward export expansion across institutional distance positively affects firm performance, but rapid downward expansion should be generally avoided. Second, entrepreneurs should strategically consider a liberalized subnational region for their main location of operations. This insight is particularly pertinent in emerging markets in which entrepreneurs usually observe substantial differences across regions in terms of their progress in institutional improvement.

\section{ACKNOWLEDGEMENTS}

The authors are grateful to the comments received from the editors John Cantwell, Shige Makino, Ram Mudambi, Gongming Qian, anonymous reviewers, Jean Boddewyn, Michael Carney, Katrin Muehlfeld, Gracy J. Yang, Daphne W. Yiu, and audience of the presentations at SMS China 2012, CUHK CIBS Summer Research Forum 2013, JIBS Paper Development Workshop 2013 (Istanbul), AIB 2013, AIB 2014, AIB 2015, JIBS Special Issue Conference 2016 (New Orleans), Renmin University of China, and University of International Business and Economics on earlier versions of this manuscript. Deng appreciates the financial support from the National Natural Science Foundation of China $(71202149 ;$ 71772175).

\section{NOTES}

${ }^{1}$ Drawing on recent literature (Chan et al., 2010; Gao, Wang, \& Che, 2017; Kirkman, Lowe, \& Gibson, 2017; Ma, Delios, \& Lau, 2013a), we adopt a broad term "subnation" for intra-national regions, although different countries use different terms, e.g., provinces, states, prefectures, counties, boroughs, and towns.

${ }^{2}$ Most non-tariff measures (NTMs) occur between developed countries rather than between developed and developing countries (WTO, 2012, pp. 114-115).

${ }^{3}$ Admittedly, the home market competition caused by liberalization may lead to a lower price and profit margin for the products sold at the home market. Nonetheless, INVs have significant sales contributed by the export market. Therefore, the cost reduction in the exported products, caused by home market liberalization, leads to an improved cost structure and stronger profitability in the overseas markets.

${ }^{4}$ Endogeneity refers to a scenario in which an independent variable is correlated with the error term of the regression model (Wooldridge, 2002b, p. 28). A main source of endogeneity is a set of omitted variables that should have been included in the regression but are difficult to measure explicitly (Wooldridge, 2002a, p. 105). For example, the strategies of firm export expansion are formulated by managers with consideration of internal resources and the external environment. At the same time, these internal and external factors directly affect the performance and survival of business operations (Chang \& Rhee, 2011; Mudambi \& Zahra, 2007). Simply running an ordinary least squares regression between endogenous variables (e.g., export expansion) and dependent variables (e.g., performance) leads to inconsistent coefficients (Wooldridge, 2002a, p. 83).

${ }^{5}$ Instrumental variables should not be included in the second-stage regressions of 2SLS estimation. The independent variable (i.e., speed) in the second stage is fitted values obtained from the first-stage regression where the instrumental variables are included. The fitted value of speed is highly correlated with the instrumental variables. If one erroneously includes the instrumental variable in the second stage, that leads to severe multicollinearity problems.

${ }^{6}$ The results of the first-stage model are available upon request.

${ }^{7}$ The coefficient of home market liberalization, as a control variable, is negative throughout the four models though. It suggests that the crowding-out effect in the home market outweighs the enabling effect on the overall ROS. The result is consistent with the finding in a recent study employing a highly similar sample (Chang \& Wu, 2014, p. 1115). That negative direct effect is not contradictory with the positive moderating effect of home market liberalization. INVs in our sample have export intensity with $42 \%$. While the crowding-out effect mainly applies to the sales in the home market sales, the enabling effect mainly applies to rapid expansion in the export market.

${ }^{8}$ Results are available upon request. We thank an editor (Gongming Qian) and an anonymous reviewer for suggesting four sets of robustness test.

${ }^{9}$ For example, a manufacturer in China (institutional score: 51 ) exports $50 \%$ upwardly to Australia (institutional score: 77 ) and $50 \%$ downwardly to Nigeria (institutional score: 45). In this case, the exporter's organizational routines may be strongly affected by the pro-market institutions in Australia, since the China-Australia difference is 26 versus the ChinaNigeria difference is only 6 (in terms of institutional scores). Therefore, it accurately measures the effect of institutional distance on firm operations to include 
both institutional distance and export share in calculating a weighted institutional distance (Zhou \& Guillén, 2015).

${ }^{10}$ Suppose a Chinese clothing manufacturer that begins export expansion in 2002. It exports to India, Nigeria, Thailand, and Australia with USD 50,000 in 2004. Each destination country accounts for $25 \%$ of the total sales. In that year, the trade openness scores

\section{REFERENCES}

Aiken, L. S., \& West, S. G. 1991. Multiple regression: Testing and interpreting interactions. Newbury Park, CA: SAGE.

Autio, E., Sapienza, H. J., \& Almeida, J. G. 2000. Effects of age at entry, knowledge intensity, and imitability on international growth. Academy of Management Journal, 43(5): 909-924.

Baggs, J., \& Brander, J. A. 2006. Trade liberalization, profitability, and financial leverage. Journal of International Business Studies, 37(2): 196-211.

Barnett, W. P., \& McKendrick, D. G. 2004. Why are some organizations more competitive than others? Evidence from a changing global market. Administrative Science Quarterly, 49(4): 535-571.

Berry, H., Guillén, M. F., \& Zhou, N. 2010. An institutional approach to cross-national distance. Journal of International Business Studies, 41(9): 1460-1480.

Boehe, D. M., Qian, G., \& Peng, M. W. 2016. Export intensity, scope, and destinations: Evidence from Brazil. Industrial Marketing Management, 57: 127-138.

Burke, A., \& Hussel, S. 2013. How competition strengthens start-ups. Harvard Business Reviev, 91(3): 24.

Cantwell, J., Dunning, J. H., \& Lundan, S. M. 2010. An evolutionary approach to understanding international business activity: The co-evolution of MNEs and the institutional environment. Journal of International Business Studies, 41(4): 567-586.

Cassiman, B., \& Golovko, E. 2011. Innovation and internationalization through exports. Journal of International Business Studies, 42(1): 56-75.

Cavusgil, S. T., \& Knight, G. 2015. The born global firm: An entrepreneurial and capabilities perspective on early and rapid internationalization. Journal of International Business Studies, 46(1): 3-16.

Chan, C., Makino, S., \& Isobe, T. 2010. Does subnational region matter? Foreign affiliate performance in the United States and China. Strategic Management Journal, 31(11): 1226-1243.

Chan, C. M., \& Makino, S. 2007. Legitimacy and multi-level institutional environments: Implications for foreign subsidiary ownership structure. Journal of International Business Studies, 38(4): 621-638.

Chandra, Y. 2017. A time-based process model of international entrepreneurial opportunity evaluation. Journal of International Business Studies, 48(4): 423-451.

Chang, S.-J., \& Rhee, J. H. 2011. Rapid FDI expansion and firm performance. Journal of International Business Studies, 42(8): 979-994.

Chang, S. J., \& Wu, B. 2014. Institutional barriers and industry dynamics. Strategic Management Journal, 35(8): 1103-1123.

Chatterjee, S., \& Shih, G. 2014. Xiaomi's India smartphone ban exposes wider patent risk. Reuters. December 14.

Coviello, N. E. 2015. Re-thinking research on born globals. Journal of International Business Studies, 46(1): 17-26.

Cuervo-Cazurra, A., \& Dau, L. A. 2009. Promarket reforms and firm profitability in developing countries. Academy of Management Journal, 52(6): 1348-1368.

Cuervo-Cazurra, A., \& Genc, M. 2008. Transforming disadvantages into advantages: Developing-country MNEs in the least of these five countries are 24 (India), 45 (Nigeria), 51 (China), 66 (Thailand), and 77 (Australia). The firmlevel weighted upward expansion speed can be calculated as $[(66-51) * 25 \%+(77-51) * 25 \%] /$ $(2004-2002+1)=3.42$. The weighted downward expansion speed is $[(51-24) * 25 \%+(51-45)$ * $25 \%] /(2004-2002+1)=2.75$.

developed countries. Journal of International Business Studies, 39(6): 957-979.

Daniels, J. D., Radebaugh, L. H., \& Sullivan, D. P. 2014 International business: Environment and operations. 15th ed. Upper Saddle River, NJ: Pearson Education.

Dau, L. A. 2013. Learning across geographic space: Pro-market reforms, multinationalization strategy, and profitability. Journal of International Business Studies, 44(3): 235-262.

De Clercq, D., Sapienza, H. J., Yavuz, R. I., \& Zhou, L. X. 2012. Learning and knowledge in early internationalization research: Past accomplishments and future directions. Journal of Business Venturing, 27(1): 143-165.

Deng, Z., Jean, R.-J. B., \& Sinkovics, R. R. 2017. Polarizing effects of early exporting on exit. Management International Review, 57(2): 243-275.

Edwards, S. 1993. Openness, trade liberalization, and growth in developing-countries. Journal of Economic Literature, 31(3): 1358-1393.

Fan, G., Wang, X., \& Zhu, H. 2011. NERI index of marketization of China's provinces 2011 report. Beijing: Economic Science Press (in Chinese).

Gao, G. Y., Wang, D. T., \& Che, Y. 2017. Impact of historical conflict on FDI location and performance: lapanese investment in China. Journal of International Business Studies. DOI:10.1057/s41267-016-0048-6.

Hashai, N. 2011. Sequencing the expansion of geographic scope and foreign operations by "born global" firms. Journal of International Business Studies, 42(8): 995-1015.

Holmes, R. M., Miller, T., Hitt, M. A., \& Salmador, M. P. 2013. The interrelationships among informal institutions, formal institutions, and inward foreign direct investment. Journal of Management, 39(2): 531-566.

International Monetary Fund. 2015. World economic outlookUneven growth: Short- and long-term factors. Washington, DC: International Monetary Fund.

Jean, R.-J. B., Deng, Z., Kim, D., \& Yuan, X. 2016. Assessing endogeneity issues in international marketing research. International Marketing Review, 33(3): 483-512.

Johanson, J., \& Vahlne, J.-E. 1977. The internationalization process of the firm-A model of knowledge development and increasing foreign market commitments. Journal of International Business Studies, 8(1): 23.

Kaufmann, D., \& Kraay, A. 2016. Worldwide governance indicators. Washington DC: World Bank.

Keats, B. W., \& Hitt, M. A. 1988. A causal model of linkages among environmental dimensions, macro organizational characteristics, and performance. Academy of Management Journal, 31(3): 570-598.

Khandelwal, A. K., Schott, P. K., \& Wei, S.-J. 2013. Trade liberalization and embedded institutional reform: Evidence from Chinese exporters. American Economic Review, 103(6): 2169-2195.

Kirkman, B. L., Lowe, K. B., \& Gibson, C. B. 2017. A retrospective on culture's consequences: The 35-year journey. Journal of International Business Studies, 48(1): 12-29. 
Kostova, T. 1999. Transnational transfer of strategic organizational practices: A contextual perspective. Academy of Management Review, 24(2): 308-324.

Kuivalainen, O., Sundqvist, S., \& Servais, P. 2007. Firms' degree of born-globalness, international entrepreneurial orientation and export performance. Journal of World Business, 42(3): 253-267.

Le, S., \& Kroll, M. 2017. CEO international experience: Effects on strategic change and firm performance. Journal of International Business Studies, 48(5): 573-595.

Levinsohn, J., \& Petrin, A. 2003. Estimating production functions using inputs to control for unobservables. Review of Economic Studies, 70(2): 317-341.

Li, L., Qian, G., \& Qian, Z. 2012. Early internationalization and performance of small high-tech "born-globals". International Marketing Review, 29(5): 536-561.

Li, L., Qian, G., \& Qian, Z. 2015. Speed of internationalization: Mutual effects of individual- and company-level antecedents. Global Strategy Journal, 5(4): 303-320.

Lu, J. W., \& Beamish, P. W. 2001. The internationalization and performance of SMEs. Strategic Management Journal, 22(6/7): 565-586.

Ma, X., Delios, A., \& Lau, C.-M. 2013a. Beijing or Shanghai? The strategic location choice of large MNEs' host-country headquarters in China. Journal of International Business Studies, 44(9): 953-961.

Ma, X. F., Tong, T. W., \& Fitza, M. 2013b. How much does subnational region matter to foreign subsidiary performance? Evidence from Fortune global 500 corporations' investment in China. Journal of International Business Studies, 44(1): 66-87.

Makino, S., Isobe, T., \& Chan, C. M. 2004. Does country matter? Strategic Management Journal, 25(10): 1027-1043.

McDougall, P. P., \& Oviatt, B. M. 2000. International entrepreneurship: The intersection of two research paths. Academy of Management Journal, 43(5): 902-906.

Melitz, M. J. 2003. The impact of trade on intra-industry reallocations and aggregate industry productivity. Econometrica, 71(6): 1695-1725.

Miller, A. T., Holmes, K. R., Feulner, E. J., Kim, A. B., Riley, B., \& Roberts, J. M. 2012. 2012 index of economic freedom. Washington, DC \& New York: The Heritage Foundation \& The Wall Street Journal.

Mudambi, R., \& Zahra, S. A. 2007. The survival of international new ventures. Journal of International Business Studies, 38(2): 333-352.

O'Grady, S., \& Lane, H. W. 1996. The psychic distance paradox. Journal of International Business Studies, 27(2): 309-333.

OECD. 2016. Financing SMEs and entrepreneurs 2016: An OECD scoreboard. Paris: OECD.

OECD. 2011. ISIC rev. 3 technology intensity definition: Classification of manufacturing industries into categories based on $R \& D$ intensities. Paris: OECD.

Oviatt, B., \& McDougall, P. 1994. Toward a theory of international new ventures. Journal of International Business Studies, 25(1): 45

Oviatt, B. M., \& McDougall, P. P. 2005. Defining international entrepreneurship and modeling the speed of internationalization. Entrepreneurship: Theory and Practice, 29(5): 537-554.

Palmer, T. B., \& Wiseman, R. M. 1999. Decoupling risk taking from income stream uncertainty: A holistic model of risk. Strategic Management Journal, 20(11): 1037-1062.

Park, S. H., Li, S. M., \& Tse, D. K. 2006. Market liberalization and firm performance during China's economic transition. Journal of International Business Studies, 37(1): 127-147.

Pavcnik, N. 2002. Trade liberalization, exit, and productivity improvements: Evidence from Chilean plants. Review of Economic Studies, 69(1): 245-276.

Perkins, S. E. 2014. When does prior experience pay? Institutional experience and the multinational corporation. Administrative Science Quarterly, 59(1): 145-181.
Qian, G., Khoury, T. A., Peng, M. W., \& Qian, Z. 2010. The performance implications of intra- and inter-regional geographic diversification. Strategic Management Journal, 31(9): 1018-1030.

Rahaman, M. M. 2016. Chinese import competition and the provisions for external debt financing in the US. Journal of International Business Studies, 47(8): 898-928.

Reeb, D., Sakakibara, M., \& Mahmood, I. P. 2012. From the editors: Endogeneity in international business research. Journal of International Business Studies, 43(3): 211-218.

Reuber, A. R., Dimitratos, P., \& Kuivalainen, O. 2017. Beyond categorization: New directions for theory development about entrepreneurial internationalization. Journal of International Business Studies, 48(4): 411-422.

Sapienza, H. J., Autio, E., George, G., \& Zahra, S. A. 2006. A capabilities perspective on the effects of early internationalization on firm survival and growth. Academy of Management Review 31(4): 914-933.

Sargan, J. D. 1958. The estimation of economic relationships using instrumental variables. Econometrica, 26(3): 393-415.

Shinkle, G. A., \& Kriauciunas, A. P. 2010. Institutions, size and age in transition economies: Implications for export growth. Journal of International Business Studies, 41(2): 267-286.

Sojli, E., \& Tham, W. W. 2017. Foreign political connections. Journal of International Business Studies, 48(2): 244-266.

Stahl, K. G., Tung, L. R., Kostova, T., \& Zellmer-Bruhn, M. 2016. Widening the lens: Rethinking distance, diversity, and foreignness in international business research through positive organizational scholarship. Journal of International Business Studies, 47(6): 621-630.

Sui, S., \& Baum, M. 2014. Internationalization strategy, firm resources and the survival of SMEs in the export market. Journal of International Business Studies, 45(7): 821-841.

Tsang, E. W. K., \& Yip, P. S. L. 2007. Economic distance and the survival of foreign direct investments. Academy of Management Journal, 50(5): 1156-1168.

Turnbull, J., et al., (Eds.). 2010. Oxford advanced learner's dictionary. 8th ed. Oxford, England: Oxford University Press.

Vermeulen, F., \& Barkema, H. 2002. Pace, rhythm, and scope: Process dependence in building a profitable multinational corporation. Strategic Management Journal, 23(7): 637-653.

Wooldridge, J. M. 2002a. Econometric analysis of cross section and panel data. Cambridge, MA: MIT Press.

Wooldridge, J. M. 2002b. Introductory econometrics: A modern approach. 2nd ed. New York: Thomson Learning.

World Bank. 2016. Doing business 2016: Measuring regulatory quality and efficiency. Washington, DC: World Bank.

World Bank. 2015. Doing business in Poland 2015: Comparing business regulations for domestic firms in 18 cities with 188 other economies. Washington, DC: World Bank.

WTO. 2013. Trade policy review, report by the secretariat, Brazil. Geneva: WTO.

WTO. 2012. World trade report 2012. Trade and public policies: $A$ closer look at non-tariff measures in the 21st century. Geneva: WTO.

Xia, J., Ma, X., Lu, J. W., \& Yiu, D. W. 2014. Outward foreign direct investment by emerging market firms: A resource dependence logic. Strategic Management Journal, 35(9): 1343-1363.

Yamin, M., \& Sinkovics, R. R. 2006. Online internationalisation, psychic distance reduction and the virtuality trap. International Business Review, 15(4): 339-360.

Zaheer, S., Schomaker, M. S., \& Nachum, L. 2012. Distance without direction: Restoring credibility to a much-loved construct. Journal of International Business Studies, 43(1): $18-27$.

Zhou, K. Z., Tse, D. K., \& Li, J. J. 2006. Organizational changes in emerging economies: Drivers and consequences. Journal of International Business Studies, 37(2): 248-263. 
Zhou, N., \& Guillén, M. F. 2015. From home country to home base: A dynamic approach to the liability of foreignness. Strategic Management Journal, 36(6): 907-917.

\section{ABOUT THE AUTHORS}

Ziliang Deng (PhD, Nottingham) is Associate Professor of International Business at Renmin Business School, Renmin University of China, Beijing. His main research interests are international entrepreneurship, international knowledge management, and institution-related global strategies.

Ruey-Jer "Bryan" Jean (PhD, Manchester) is Professor of International Business at the Department of International Business, National Chengchi University, Taipei. His research focuses on interorganizational relationship management and international new ventures in digital and data-rich environments, with a focus on emerging markets.
Rudolf R Sinkovics (PhD, WU Vienna) is Professor of International Business at The University of Manchester, Manchester, Visiting Professor at Lappeenranta University of Technology, Lappeenranta, and Visiting Scholar at Fox School of Business, Temple University, Philadelphia. He has published on inter-organizational governance, the role of ICT in firm internationalization, and currently works on rising powers and responsible business.

Open Access This article is distributed under the terms of the Creative Commons Attribution 4.0 International License (http://creativecommons. org/licenses/by/4.0/), which permits unrestricted use, distribution, and reproduction in any medium, provided you give appropriate credit to the original author(s) and the source, provide a link to the Creative Commons license, and indicate if changes were made. 